Identification of the physio-chemical processes controlling the composition of groundwater at Wadi EI Tumilat area, East Nile Delta, Egypt

\author{
Eslam R. Soliman ${ }^{1}$, Reda G.M. Ibrahim ${ }^{1}$, Eglal R. Souaya ${ }^{2}$, Yousra H. Kotp ${ }^{1}$ and \\ Khairia A. Gindy ${ }^{1}$
}

${ }^{1}$ Hydrogeochemistry Department, Desert Research Center, Cairo, Egypt, 11753

${ }^{2}$ Chemistry Department, Ain Shams University, Cairo, Egypt, 11566

Received: 15 Oct. 2019 / Accepted 15 Dec. 2019 / Publication date: 20 Dec. 2019

\begin{abstract}
Wadi El Tumilat is located to the northeast of Cairo and to the west of Ismailia City. The Quaternary deposits represent the main water-bearing formation at depths range from 5 to $70 \mathrm{~m}$. The aquifer matrix is built up from fluviatile and fluviomarine graded sand and gravel with clay intercalations of limited extension. It rests directly with unconformity surface on the Miocene hard limestone. This aquifer is recharged mainly from surface water system especially Ismailia and El Manaief canals and to less extent from the upward leakage from the Miocene aquifer at the southern part of the study area. The connection between the two aquifers is highly controlled by the presence of deep-seated faults. The groundwater extracted from the Quaternary aquifer is mainly fresh to brackish (TDS= 194.7 to $4916.4 \mathrm{mg} / \mathrm{l}$ ), while only $10 \%$ of samples are saline (TDS=5380 to $6407.6 \mathrm{mg} / \mathrm{l}$ ). The main objective of the present study is to delineate the main hydrogeochemical and hydrological processes affecting groundwater quality using the conventional geochemical tools and multivariate statistical techniques. Box plots are also used to show the content and distribution of major constituents in the investigated groundwater. The ionic ratios and statistical analyses showed that ion exchange (mainly of reverse type), silicate weathering, evaporation and mixing with surface water and/or Miocene groundwater are the main dominant processes controlling the groundwater quality of the Quaternary aquifer at Wadi El Tumilat area. Future study of the hydrogeochemistry of this aquifer will consider the quantitative assessment of the prevailing hydrogeochemical processes especially evaporation and mixing using appropriate geochemical modeling technique.
\end{abstract}

Keywords: Ion exchange, Silicate weathering, Mixing, Cluster analysis, Wadi El Tumilat area, Egypt.

\title{
Introduction
}

Wadi El Tumilat extends from east of the $10^{\text {th }}$ of Ramadan City until Ismailia city. It is located in the southeastern quarter of east Delta area, where it lies between latitudes $30^{\circ} 35^{`}$ and $30^{\circ} 60^{`} \mathrm{~N}$ and longitudes $31^{\circ} 70^{\backslash}$ and $32^{\circ} 15^{\backslash} \mathrm{E}$ (Fig. 1). The total area of Wadi El Tumilat is $1500 \mathrm{~km}^{2}$ (Ismail, 2008). Wadi El Tumilat area is characterized by arid climate. It is hot and dry in summer, cold and rainy in winter.

Studying the hydrogeochemical processes affecting groundwater quality helps to get an insight into the contribution of water-rock interactions and anthropogenic influences on groundwater composition. The present study aims to evaluate the water-rock interactions represented by the processes of ion exchange, dissolution and precipitation, which control the Quaternary groundwater composition at Wadi El Tumilat area under arid and semi-arid conditions. Understanding such hydrogeochemical processes contribute to the proper management strategies and enable for good utilization of groundwater resources.

\section{Physical setting}

Geomorphologically, Wadi El Tumilat represents a part of the eastern gravelly slopes fringing the Nile Delta and bears the structural affinity of the Syrian arc system. The northern limit is defined by the well-known buried Nile branch (Pelusaic) which extends in NE-SW direction and is represented by a semi flat plain called El Salhia plain (Fig. 2). El Timsah and Bitter lakes represent the remnants of an old structural and topographic low land area called "Isthmus Stretch" along the eastern boundaries. The southern boundary of Wadi El-Tumilat is represented by Umm Gidam

Corresponding Author: Reda Gamil Mohamed Ibrahim, Hydrogeochemistry Department, Desert Research Center, Cairo, Egypt, 11753. E-mail: redagad75@hotmail.com 
gravelly sand sheets in the form of low-lying slopes. This southern boundary is also determined by a series of structural ridges extend in an E-W trend. The foreland slopes of the southern structural ridges are dissected by few morpho-tectonic main drainage lines, mostly of NW-SE trend with numerous dendritic tributaries see (Fig. 2). In general, the average slope of Wadi El-Tumilat reaches $6 \mathrm{~cm} / \mathrm{km}$ from west to east direction. Its average ground surface elevation is about $40 \mathrm{~m}$ above mean sea level (Ismail, 2008).
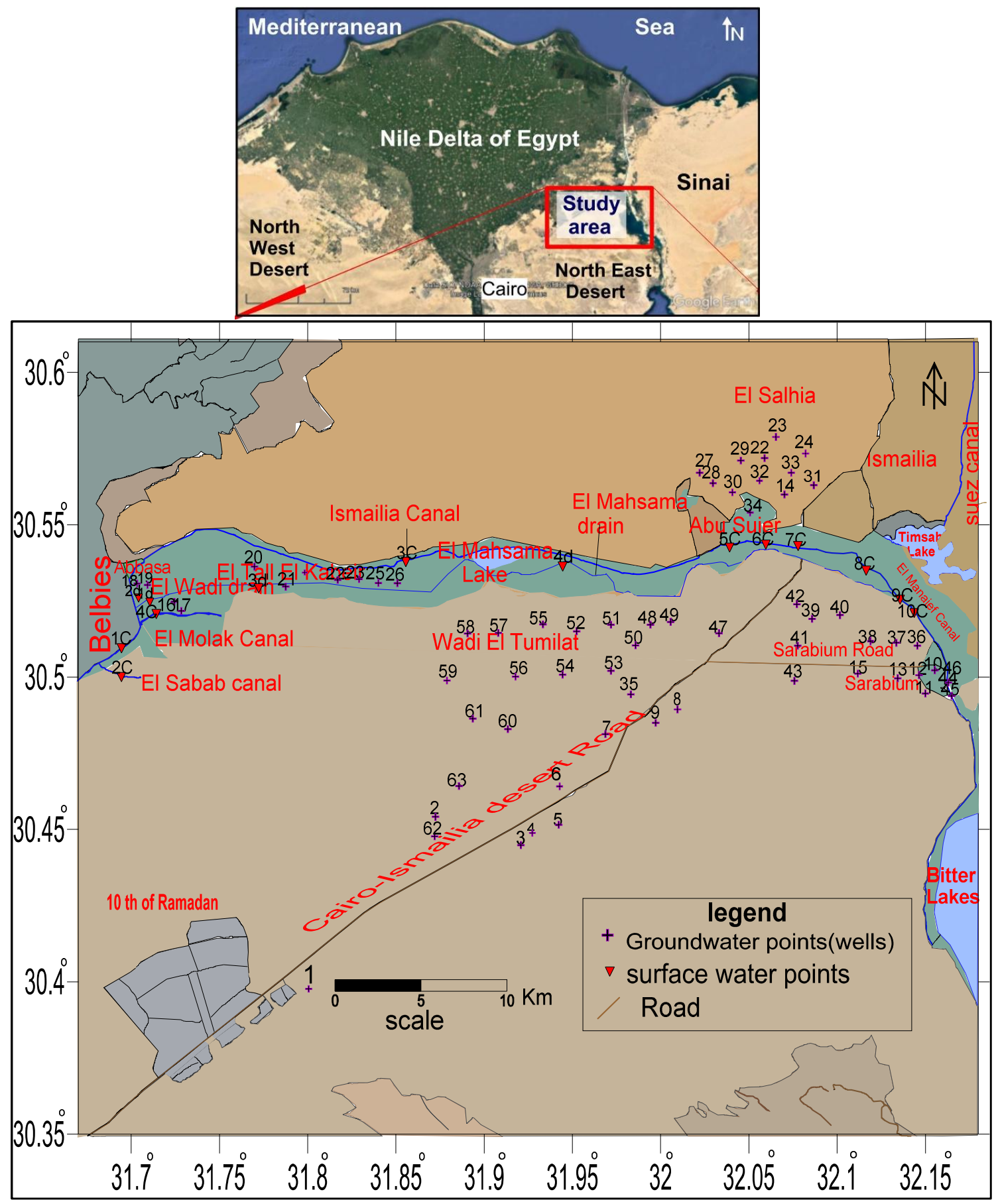

Fig. 1: Location map of Wadi El Tumilat area, Egypt, showing the sampling sites. 


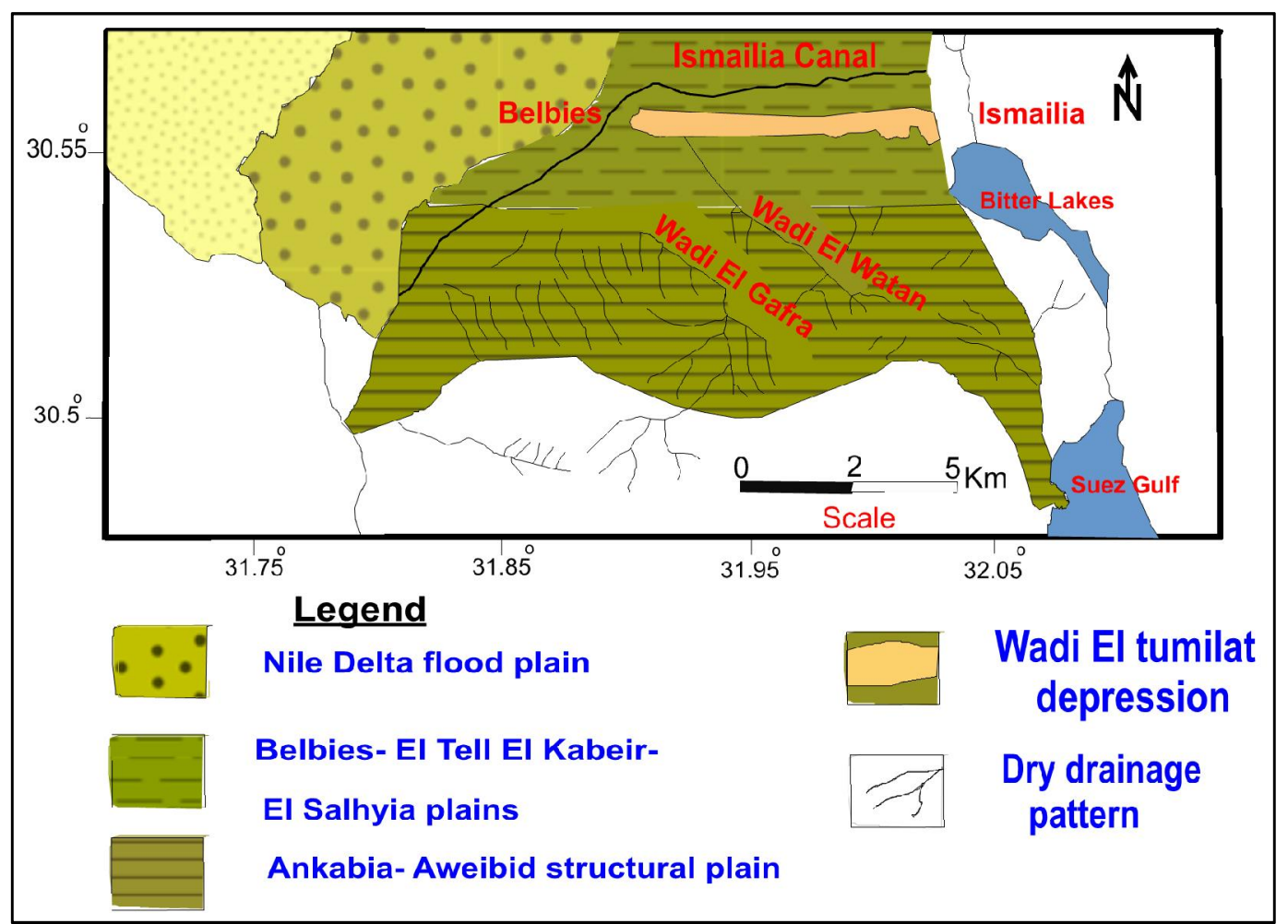

Fig. 2: Geomorphologic map of Wadi El Tumilat area, Egypt (modified after Shata, 1965)

The lithology of Wadi El-Tumilat consists of unconsolidated Quaternary sediments that covering variable geomorphic features from the high hill slopes, the flat braided streams and the flooded plains to the structural depressions and lowlands (El Fawal, 1992 \& Greish, 1994). These Quaternary sediments exhibit more than $200 \mathrm{~m}$ thick of braided river sediments to the north and fan type sediments to the east at the valley outlet. The flood plain of Wadi El Tumilat is formed by flooding sedimentation, which drained into the eastern lowlands (Isthmus stretch). Later, this stretch has connected to the Gulf of Suez open sea, leading to the formation of gypsiferous sabkhas of marine sedimentary type that overlain the flood plain sedimentation. Wadi El Tumilat facies include the sediment deposited by the meandering river system of Wadi El Tumilat distributaries. These facies usually consist of fine to silty sands, sometimes calcareous to slightly gypsiferous, especially in the eastern part (Fig. 3) (El Fawal \& Shendi, 1991).

\section{Hydrogeological setting}

Hydrogeologically, the Quaternary aquifer of Wadi El Tumilat represents the main aquifer in the region. It is composed of fluviatile and fluviomarine graded sand and gravel with clay intercalations of limited extension. The basal portion of this aquifer is formed of dark plastic clay. The Quaternary deposits rest directly with unconformity surface on the Miocene hard limestone as recognized in the north and south of Wadi El-Tumilat. Its total thickness increases generally from south to north. It is mainly recharged by Nile water from the river branches and canals (mainly Ismailia and El Manaief canals). The depth to the Quaternary groundwater surface ranges from 5 to $70 \mathrm{~m}$ (Fig. 4). Furthermore, the groundwater is flowing at few wells near El Tel El kebeir city. The Miocene aquifer is dominated by clastic facies in the southern part of the study area and overlain by about $200 \mathrm{~m}$ of Quaternary deposits (Fig. 5). In Belbies-El Tell El Kabier-El Salhiya fluviatile plain, the Miocene sediments are composed of alternating sandy limestone and clay lenses, loose quartz sand and marl. The aquifer is more clayey towards east. In the narrow strip adjacent to the Ismailia canal, the depth to the groundwater is highly affected by the level of surface water running in this canal. This means that there is a mutual relationship (interaction) between surface and groundwater at the area adjacent to Ismailia Canal in the area under consideration (Dahab et al., 2007). 


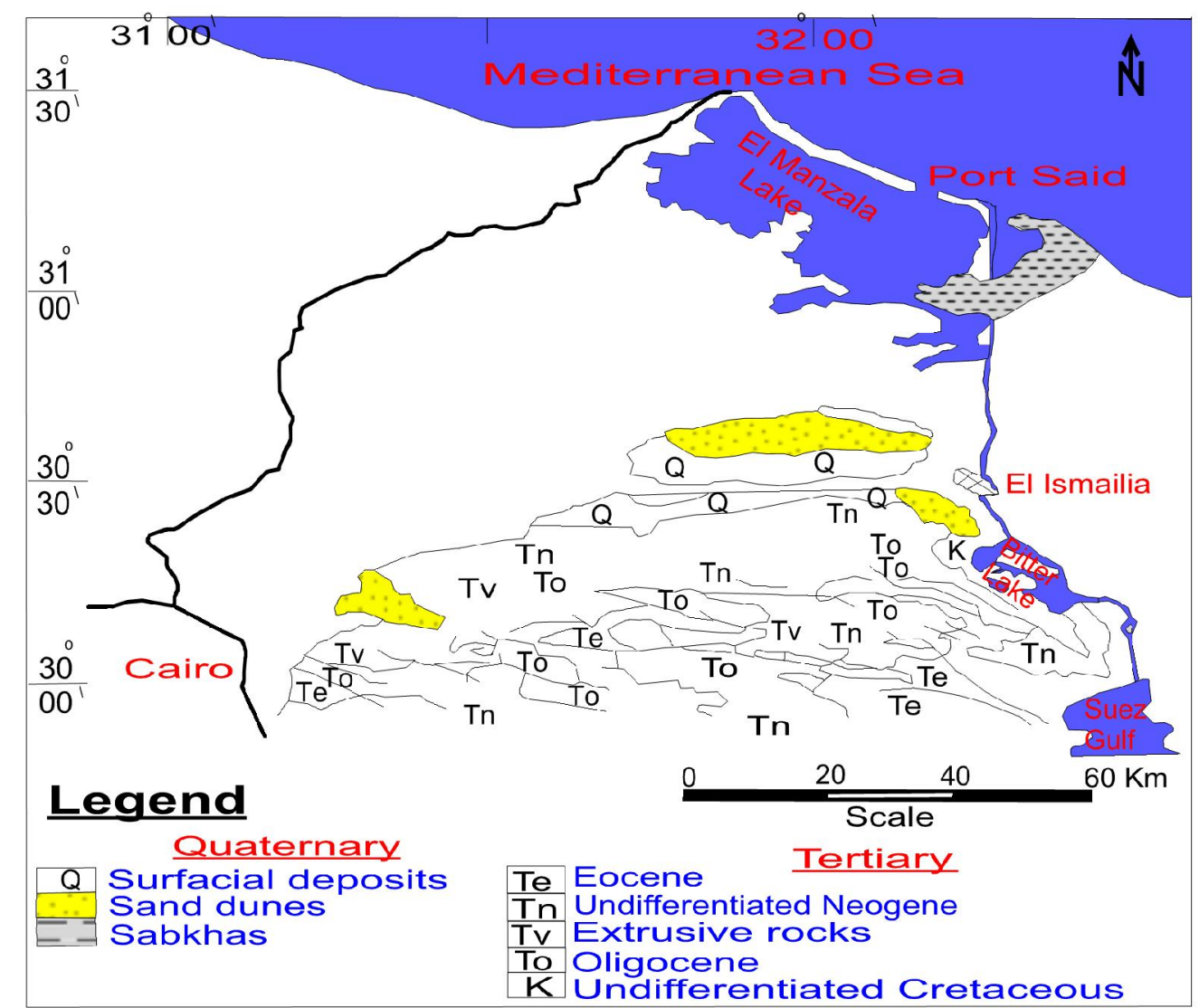

Fig. 3: Compiled geological map of Wadi El Tumilat area, Egypt (after Sallouma, 1983).

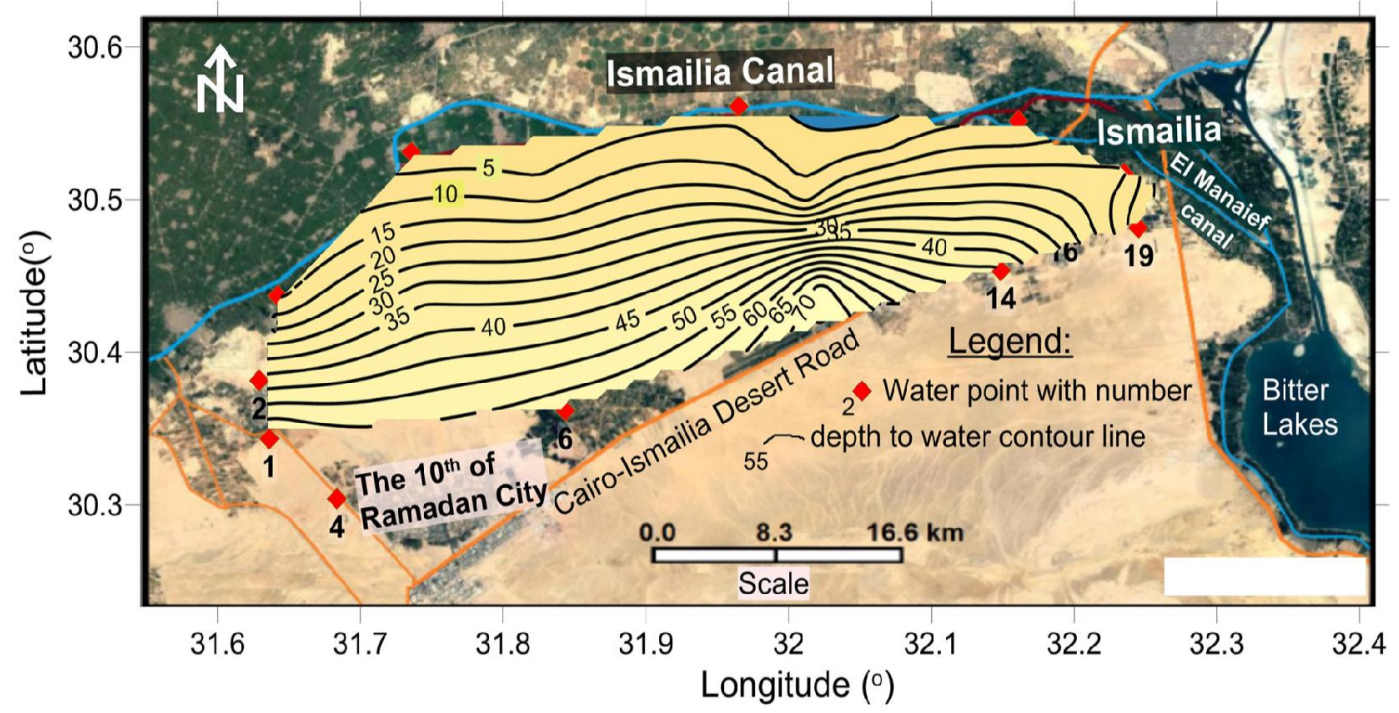

Fig. 4: Depth to water contour map of the Quaternary aquifer at Wadi El Tumilat area, (after El Sayed, 2018). 


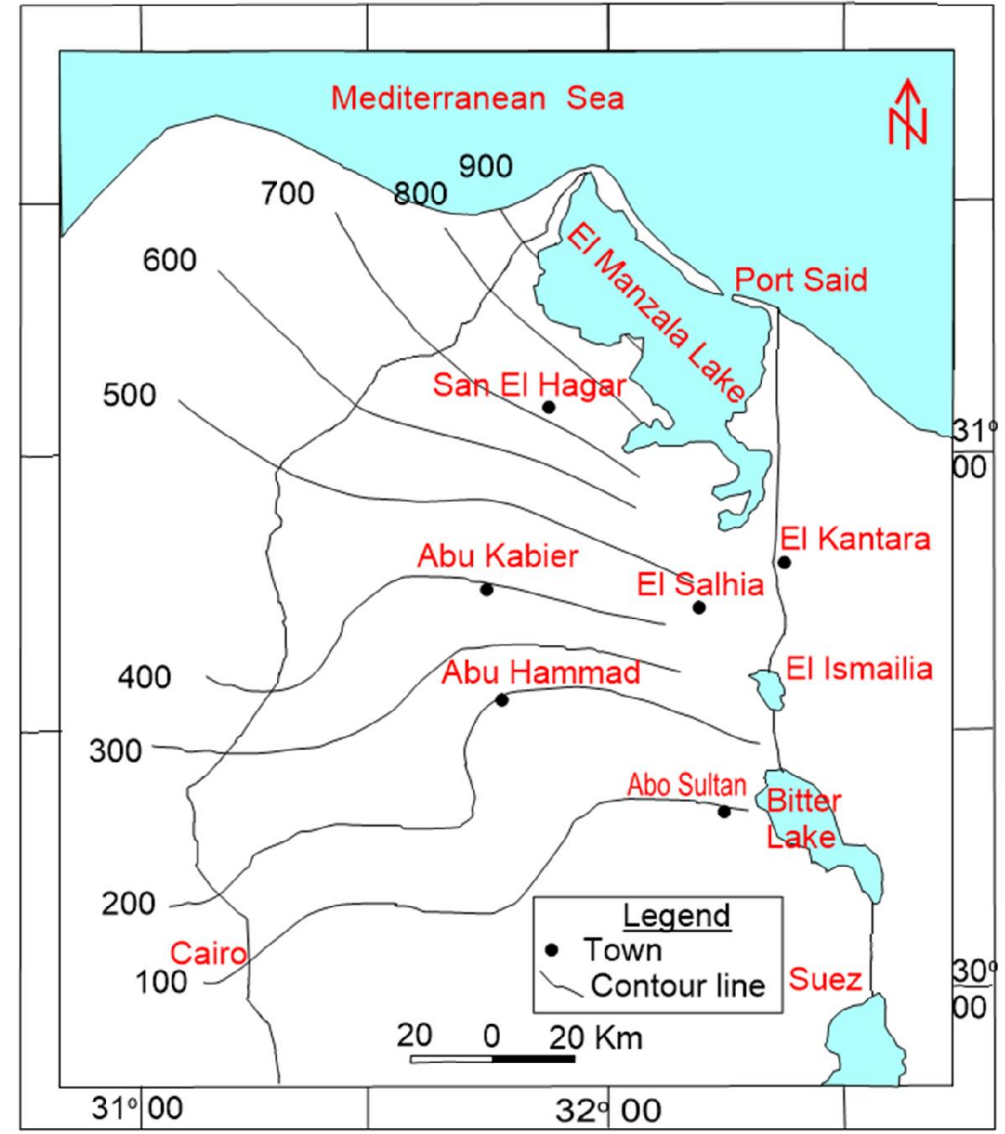

Fig. 5: Isopach contour map of the Quaternary aquifer thickness, east of the Nile Delta including Wadi El Tumilat area (after Hefny, 1980).

The Quaternary aquifer in the study area is unconfined in the western part and semi-confined in the eastern part due to the presence of capped and underlying clay beds. This aquifer is characterized by a multiple and divergent water flow paths that seems to be the product of the structural setting and heterogeneity of the aquifer materials. Based on water level measurements 2017, the groundwater flow direction is mainly from south to north in the southern part of the study area (i.e., from the Miocene aquifer at the south) with very low hydraulic gradient $\left(\approx 2 \times 10^{-4}\right)$. An opposite direction is recorded from north to south in the area lying south of Ismailia canal, where the hydraulic gradient $\approx$ $4 \times 10^{-4}$ (Fig. 6), (El Sayed, 2018).

Ismailia canal is the main recharging source of groundwater in the study area beside Suez and El-Manaief fresh water canals. In the Western and eastern parts of the Quaternary aquifer of Wadi El Tumilat, a general trend of discharge is in the W-E direction due to the intensive pumping of groundwater for reclamation projects at Wadi El-Mullak, El-Manaief and Sarabium areas (Ismail, 2008). The main drainage network (El Mahsama drain, El Mahsama Lake, El Karnak Lake, El Manaief Lake and Sarabium Lake) play a significant role in the groundwater pollution in the Quaternary aquifer of Wadi El Tumilat based on its vulnerability.

It is worth to mention that, the Quaternary aquifer of Wadi El Tumilat and the Miocene aquifer are hydraulically connected but in some places. The hydraulic connection between the two aquifers is highly controlled by the deep-seated faults which may cause of Miocene saline water to move upward recharge along their planes to Quaternary aquifer of Wadi El Tumilat (Gad, 1995\& Gad et al., 2015). 


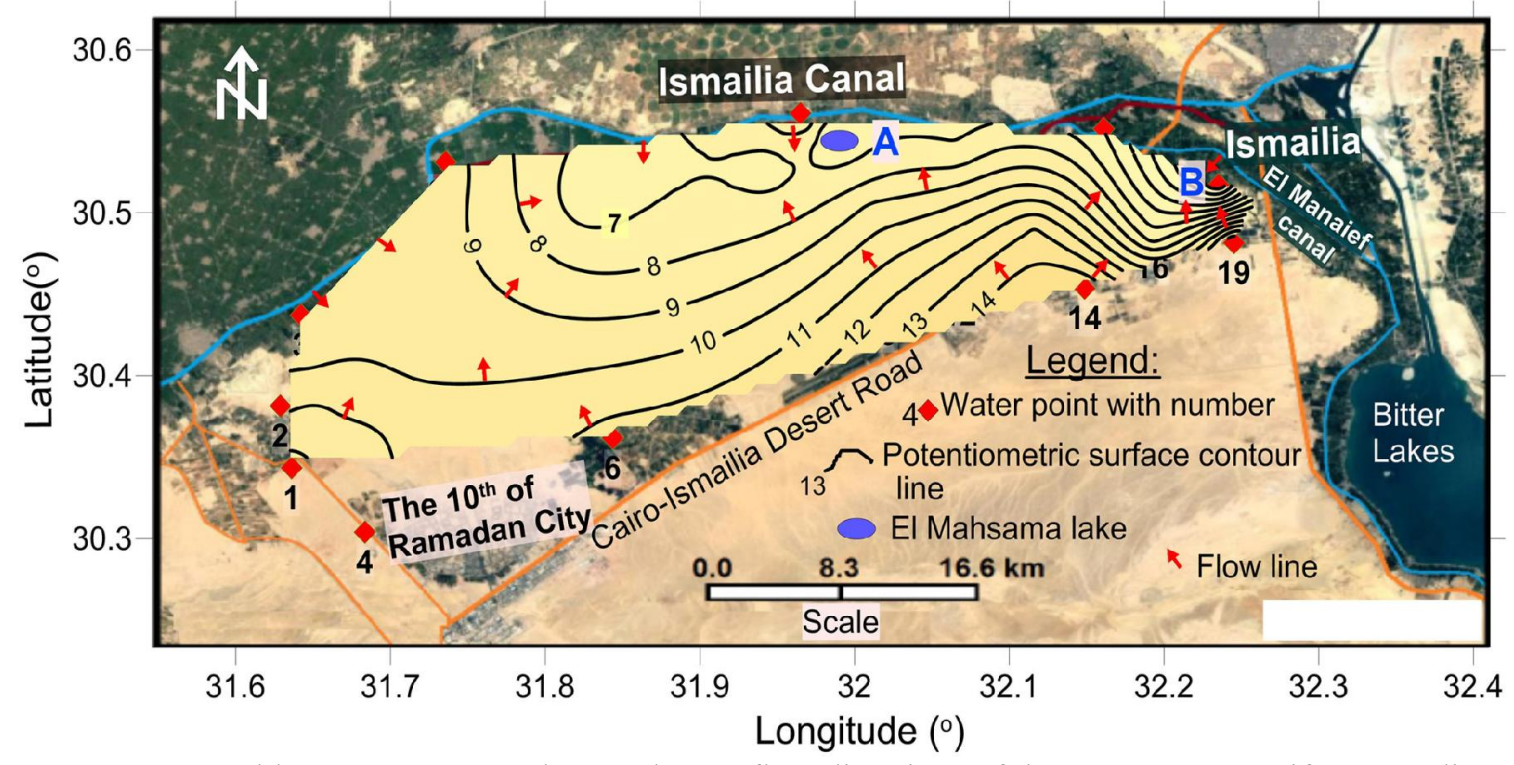

Fig. 6: Water Table contour map and groundwater flow directions of the Quaternary aquifer at Wadi El Tumilat area. (after El Sayed, 2018).

\section{Sampling and methodology}

To evaluate the variations in chemical compositions, sixty three groundwater samples were collected during April 2017, (see Fig. 1). Fifty eight samples represent the Quaternary aquifer, and ten samples represent the Miocene aquifer. The samples were preserved and analyzed according to standard methods of (Rainwater and Thatcher, 1960), (APHA, 1995) and (ASTM, 2002). The analyses were carried out by the authors at hydrogeochemistry department, Desert Research Center (DRC), Egypt. The EC and $\mathrm{pH}$ were measured in the field immediately after the collection of the samples. $\mathrm{HCO}_{3}{ }^{-}$and $\mathrm{CO}_{3}{ }^{2-}$ were measured using the titration technique (using $\mathrm{H}_{2} \mathrm{SO}_{4}$ solution). $\mathrm{Ca}^{2+}$, $\mathrm{Mg}^{2+}, \mathrm{Na}^{+}, \mathrm{K}^{+}, \mathrm{SO}_{4}{ }^{2-}, \mathrm{Cl}^{-}$concentrations were estimated using a Thermo Scientific Ion Chromatograph (IC), model Dionex, ICS-1100. Standard solutions for the above analyses were prepared from the respective salts of analytical reagent grade. The obtained chemical data are expressed in milligram per liter, (Table. 1).

Table 1: Hydrochemical analyses data of the groundwater samples collected from Wadi El Tumilat area, Egypt (2017).

\begin{tabular}{|c|c|c|c|c|c|c|c|c|c|c|c|}
\hline $\begin{array}{c}\text { Sample } \\
\text { No }\end{array}$ & $\mathbf{p H}$ & $\begin{array}{c}\mathrm{EC} \\
(\mu \mathrm{S} / \mathrm{Cm})\end{array}$ & $\begin{array}{l}\text { TDS } \\
\mathrm{mg} / \mathrm{l}\end{array}$ & $\begin{array}{c}\mathrm{Ca} \\
\mathrm{mg} / \mathrm{l}\end{array}$ & $\begin{array}{c}\text { Mg } \\
\text { mg/l }\end{array}$ & $\begin{array}{c}\text { Na } \\
\text { mg/l }\end{array}$ & $\begin{array}{c}\mathrm{K} \\
\mathrm{mg} / \mathrm{l}\end{array}$ & $\begin{array}{l}\mathrm{CO}_{3} \\
\mathrm{mg} / \mathrm{l}\end{array}$ & $\begin{array}{c}\mathrm{HCO}_{3} \\
\mathrm{mg} / \mathrm{l}\end{array}$ & $\begin{array}{l}\mathrm{SO}_{4} \\
\mathrm{mg} / \mathrm{l}\end{array}$ & $\begin{array}{c}\mathrm{Cl} \\
\mathrm{mg} / \mathrm{l}\end{array}$ \\
\hline \multicolumn{12}{|c|}{ The Quaternary aquifer } \\
\hline 2 & 7.2 & 3140 & 2046.96 & 102.16 & 30.33 & 610.9 & 2.87 & 6 & 219.6 & 644.8 & 540.1 \\
\hline 5 & 7.2 & 6270 & 3969.79 & 342.14 & 82.60 & 967.47 & 19.78 & 0 & 103.7 & 804.71 & 1701.24 \\
\hline 6 & 7.2 & 5830 & 3755.4 & 458.66 & 159.36 & 1520.6 & 15.38 & 6 & 146.4 & 606.6 & 2832.2 \\
\hline 7 & 7.1 & 6440 & 4245.51 & 273.82 & 89.14 & 1154.9 & 8.26 & 0 & 164.7 & 1036.8 & 1600.2 \\
\hline 8 & 7.1 & 5530 & 3475.04 & 261.30 & 102.60 & 906.4 & 3.26 & 0 & 305 & 717.1 & 1331.9 \\
\hline 9 & 7 & 6040 & 3977.91 & 245.21 & 84.54 & 1111.6 & 5.06 & 0 & 408.7 & 1062.8 & 1264.4 \\
\hline 10 & 7.1 & 4350 & 2835.78 & 160.27 & 57.30 & 864.1 & 4.70 & 6 & 469.7 & 676.0 & 832.6 \\
\hline 11 & 7.2 & 4500 & 2873.56 & 151.96 & 47.14 & 855.9 & 4.76 & 0 & 414.8 & 593.2 & 1013.2 \\
\hline 12 & 7 & 7320 & 4904.05 & 307.62 & 121.24 & 1303.2 & 4.49 & 0 & 305 & 1004.0 & 2011.0 \\
\hline 15 & 7.2 & 3630 & 2431.51 & 105.75 & 37.18 & 730.2 & 1.21 & 0 & 427 & 562.0 & 763.6 \\
\hline 16 & 7 & 451 & 256.33 & 33.44 & 14.16 & 35.9 & 6.52 & 0 & 183 & 48.4 & 26.4 \\
\hline 17 & 7 & 617 & 391.28 & 72.85 & 21.22 & 41.8 & 6.39 & 0 & 305 & 66.0 & 30.6 \\
\hline 18 & 7 & 346 & 208.46 & 24.54 & 10.12 & 40.6 & 5.47 & 0 & 201.3 & 20.7 & 6.3 \\
\hline 19 & 7 & 385 & 238.98 & 40.92 & 10.06 & 31.7 & 5.58 & 0 & 201.3 & 31.1 & 19.0 \\
\hline 20 & 6.7 & 1470 & 959.8 & 31.54 & 3.86 & 304.3 & 2.61 & 0 & 390.4 & 275.2 & 147.1 \\
\hline 21 & 7 & 1304 & 931.31 & 77.17 & 19.09 & 260.7 & 7.79 & 0 & 396.5 & 237.6 & 130.6 \\
\hline 22 & 7 & 2970 & 2133.33 & 136.71 & 41.02 & 554.3 & 4.05 & 0 & 347.7 & 896.5 & 326.9 \\
\hline 23 & 7.2 & 2721 & 1950.8 & 140.29 & 46.56 & 503.9 & 8.02 & 6 & 390.4 & 745.5 & 305.3 \\
\hline 24 & 7.1 & 4070 & 2512.15 & 133.28 & 53.08 & 733.4 & 12.94 & 6 & 231.8 & 493.7 & 963.9 \\
\hline
\end{tabular}


Middle East J. Appl. Sci., 9(4): 1137-1160, 2019

EISSN: 2706 -7947 ISSN: 2077-4613

\begin{tabular}{|c|c|c|c|c|c|c|c|c|c|c|c|}
\hline 25 & 7.2 & 5070 & 3594.42 & 170.43 & 49.02 & 1071.7 & 4.43 & 0 & 298.9 & 1290.9 & 858.5 \\
\hline 26 & 7.2 & 2055 & 1271.1 & 96.08 & 35.29 & 365.3 & 2.02 & 0 & 549 & 148.7 & 349.2 \\
\hline 27 & 7.2 & 4010 & 2760.48 & 171.34 & 60.59 & 760.7 & 16.87 & 6 & 463.6 & 828.9 & 684.3 \\
\hline 28 & 7.2 & 5700 & 3892.54 & 249.20 & 90.28 & 1041.8 & 6.14 & 6 & 353.8 & 1257.0 & 1065.3 \\
\hline 29 & 7.4 & 3420 & 2419.89 & 166.95 & 54.93 & 624.5 & 15.97 & 6 & 384.3 & 828.4 & 531.0 \\
\hline 30 & 7.4 & 3780 & 2597.36 & 205.57 & 67.35 & 661.9 & 3.09 & 0 & 396.5 & 782.7 & 678.5 \\
\hline 31 & 7.4 & 4390 & 2526.37 & 152.52 & 27.73 & 800.4 & 7.10 & 6 & 353.8 & 335.5 & 1020.3 \\
\hline 32 & 7.3 & 2866 & 1748.77 & 141.43 & 45.33 & 493.2 & 7.02 & 0 & 463.6 & 256.5 & 573.5 \\
\hline 33 & 7.1 & 4850 & 2974.17 & 170.27 & 47.04 & 924.7 & 4.59 & 6 & 561.2 & 561.9 & 979.0 \\
\hline 34 & 7.4 & 3600 & 2331.13 & 95.62 & 38.71 & 762.2 & 2.37 & 6 & 567.3 & 473.9 & 668.7 \\
\hline 35 & 7.4 & 597 & 318.77 & 68.12 & 11.30 & 42.1 & 0.76 & 0 & 274.5 & 42.6 & 16.6 \\
\hline 37 & 7.3 & 2238 & 1428 & 46.62 & 16.75 & 488.7 & 3.25 & 0 & 573.4 & 238.6 & 347.5 \\
\hline 38 & 7.3 & 2576 & 1675.49 & 40.88 & 8.52 & 581.4 & 4.10 & 0 & 524.6 & 339.1 & 439.1 \\
\hline 39 & 7.2 & 4920 & 3340.05 & 199.78 & 32.78 & 995.9 & 5.84 & 0 & 457.5 & 964.1 & 912.9 \\
\hline 40 & 7.2 & 4530 & 2877.15 & 172.81 & 66.11 & 843.8 & 4.66 & 0 & 536.8 & 563.7 & 957.6 \\
\hline 41 & 7.1 & 6230 & 3862.68 & 259.64 & 112.84 & 1061.6 & 6.21 & 0 & 457.5 & 764.8 & 1428.8 \\
\hline 42 & 7.1 & 8410 & 4916.42 & 308.52 & 84.70 & 1433.4 & 4.02 & 0 & 414.8 & 1023.5 & 1854.9 \\
\hline 43 & 7.5 & 3620 & 2342.04 & 80.27 & 34.41 & 757.6 & 13.16 & 6 & 536.8 & 497.4 & 684.8 \\
\hline 44 & 7.3 & 4320 & 2749.98 & 125.79 & 44.01 & 837.9 & 4.90 & 0 & 524.6 & 689.2 & 786.0 \\
\hline 47 & 7.4 & 7160 & 4848.67 & 273.57 & 83.94 & 1357.3 & 14.54 & 0 & 347.7 & 1263.9 & 1681.6 \\
\hline 48 & 7.4 & 1903 & 1103.14 & 102.51 & 18.36 & 292.6 & 9.83 & 0 & 427 & 294.6 & 171.8 \\
\hline 49 & 7.3 & 4700 & 2950.71 & 191.78 & 29.80 & 834.9 & 13.96 & 6 & 512.4 & 550.0 & 1068.1 \\
\hline 50 & 7.3 & 869 & 468 & 42.25 & 18.61 & 105.0 & 8.25 & 6 & 359.9 & 67.9 & 40.0 \\
\hline 51 & 6.8 & 4330 & 3024.25 & 209.82 & 107.08 & 727.2 & 11.77 & 0 & 957.7 & 966.2 & 523.3 \\
\hline 52 & 7 & 5190 & 3270.95 & 162.05 & 53.91 & 967.2 & 10.94 & 0 & 512.4 & 709.3 & 1111.4 \\
\hline 53 & 7 & 4480 & 2779.3 & 120.75 & 47.93 & 857.8 & 15.11 & 6 & 500.2 & 478.9 & 1002.8 \\
\hline 54 & 7.6 & 3850 & 2395.68 & 128.14 & 44.65 & 710.2 & 10.64 & 30 & 475.8 & 514.8 & 719.4 \\
\hline 55 & 7.4 & 6870 & 4453.88 & 196.56 & 76.14 & 1267.9 & 15.79 & 12 & 506.3 & 1242.2 & 1390.1 \\
\hline 56 & 7.3 & 5300 & 3281.83 & 191.27 & 68.82 & 905.4 & 11.21 & 0 & 384.3 & 654.6 & 1258.4 \\
\hline 57 & 7.1 & 6870 & 4785.57 & 263.31 & 85.40 & 1294.3 & 11.60 & 0 & 329.4 & 1357.5 & 1608.7 \\
\hline 58 & 7.2 & 4460 & 2778.39 & 128.82 & 45.03 & 832.4 & 9.78 & 6 & 390.4 & 592.6 & 968.6 \\
\hline 59 & 7.2 & 5770 & 3849.94 & 175.56 & 51.71 & 1132.5 & 11.42 & 6 & 414.8 & 1090.1 & 1175.2 \\
\hline 60 & 7.3 & 4940 & 3155.26 & 147.57 & 47.96 & 927.9 & 10.24 & 6 & 396.5 & 651.6 & 1165.8 \\
\hline 61 & 7.9 & 394 & 194.76 & 26.2 & 13.78 & 27.2 & 6.29 & 12 & 164.7 & 16.0 & 11.0 \\
\hline \multicolumn{12}{|c|}{ The Miocene aquifer } \\
\hline 1 & 6.7 & 9670 & 5499.75 & 505.47 & 182.38 & 1322.31 & 14.57 & 0 & 91.5 & 537.97 & 2891.31 \\
\hline 3 & 7.2 & 9640 & 5671.96 & 458.65 & 159.36 & 1520.60 & 15.38 & 6 & 146.4 & 606.56 & 2832.21 \\
\hline 4 & 7.2 & 9180 & 6381.51 & 490.96 & 143.21 & 1606.87 & 18.09 & 0 & 97.6 & 1320.78 & 2752.78 \\
\hline 13 & 7 & 7450 & 5379.82 & 378.63 & 114.76 & 1466.7 & 4.63 & 0 & 335.5 & 1352.7 & 1894.7 \\
\hline 14 & 7.1 & 8640 & 6407.6 & 342.98 & 121.80 & 1747.6 & 17.38 & 0 & 335.5 & 1893.4 & 2116.7 \\
\hline 36 & 7.4 & 7730 & 5606.71 & 279.80 & 96.59 & 1705.0 & 5.88 & 0 & 372.1 & 1748.8 & 1584.6 \\
\hline 45 & 7.2 & 10830 & 6369.29 & 229.41 & 70.18 & 2047.2 & 10.71 & 6 & 329.4 & 1362.2 & 2478.9 \\
\hline 46 & 7.4 & 11330 & 6055.8 & 343.80 & 139.97 & 1797.2 & 12.78 & 6 & 262.3 & 1866.4 & 1758.5 \\
\hline 62 & 7.1 & 9050 & 6049.81 & 516.77 & 140.93 & 1459.58 & 11.10 & 0 & 146.4 & 1073.42 & 2774.81 \\
\hline 63 & 7.3 & 8740 & 6205.94 & 516.78 & 140.93 & 1459.6 & 11.10 & 0 & 146.4 & 1073.4 & 2774.8 \\
\hline
\end{tabular}

\begin{tabular}{|c|c|c|c|c|c|c|c|c|c|c|c|}
\hline \multicolumn{12}{|c|}{ Surface water } \\
\hline $1 \mathrm{C}$ & 6.9 & 378 & 237.67 & 28.64 & 11.74 & 37.8 & 7.44 & 0 & 201.3 & 31.1 & 20.3 \\
\hline $2 \mathrm{C}$ & 6.6 & 385 & 238.94 & 33.17 & 13.33 & 32.6 & 5.88 & 0 & 201.3 & 32.5 & 20.8 \\
\hline $4 \mathrm{C}$ & 6.9 & 381 & 241.27 & 32.94 & 13.76 & 34.1 & 6.43 & 0 & 201.3 & 31.9 & 21.5 \\
\hline $5 \mathrm{C}$ & 6.9 & 381 & 238.31 & 32.66 & 13.40 & 36.1 & 6.03 & 0 & 195.2 & 31.8 & 20.7 \\
\hline $\begin{array}{l}8 \mathrm{C} \\
\text { El Manaif Canl }\end{array}$ & 7.1 & 416 & 249.77 & 32.80 & 13.44 & 39.9 & 6.80 & 0 & 195.2 & 32.2 & 27.0 \\
\hline $9 \mathrm{C}$ & 7.1 & 384 & 242.73 & 32.80 & 13.54 & 33.3 & 6.29 & 0 & 207.4 & 32.0 & 21.1 \\
\hline $10 \mathrm{C}$ & 6.9 & 380 & 240.12 & 32.65 & 13.69 & 33.8 & 6.70 & 0 & 201.3 & 32.2 & 20.5 \\
\hline 1d & 7.1 & 459 & 275.74 & 39.18 & 15.27 & 41.1 & 6.70 & 0 & 231.8 & 34.1 & 23.5 \\
\hline
\end{tabular}




\section{Results and Discussion}

\section{Hydrogeochemistry of surface water}

The surface water system in the study area play an important role in recharging the groundwater and so affecting its quality. The hydrogeochemistry of the surface water is discussed in the following (Table. 1):

A- $\mathrm{pH}$ of surface water samples is varying between 6.6 and 7.3 with an average value of 6.9 (Fig. 7).

B- The water salinity (TDS) average from 234.4 to $249.7 \mathrm{mg} / \mathrm{l}$ in canals and from 239 to $1228 \mathrm{mg} / \mathrm{l}$ in drains (fig.7).

C- The order of cations dominance in the surface samples are $\mathrm{Na}^{+}+\mathrm{K}^{+}>\mathrm{Ca}^{2+}>\mathrm{Mg}^{2+}$, while the order of anions are $\mathrm{HCO}_{3}{ }^{-}+\mathrm{CO}_{3}{ }^{2-}>\mathrm{Cl}^{-}>\mathrm{SO}_{4}{ }^{2-}$.

D- The water type of the surface samples is classified into two main types, bicarbonate and chloride water types.

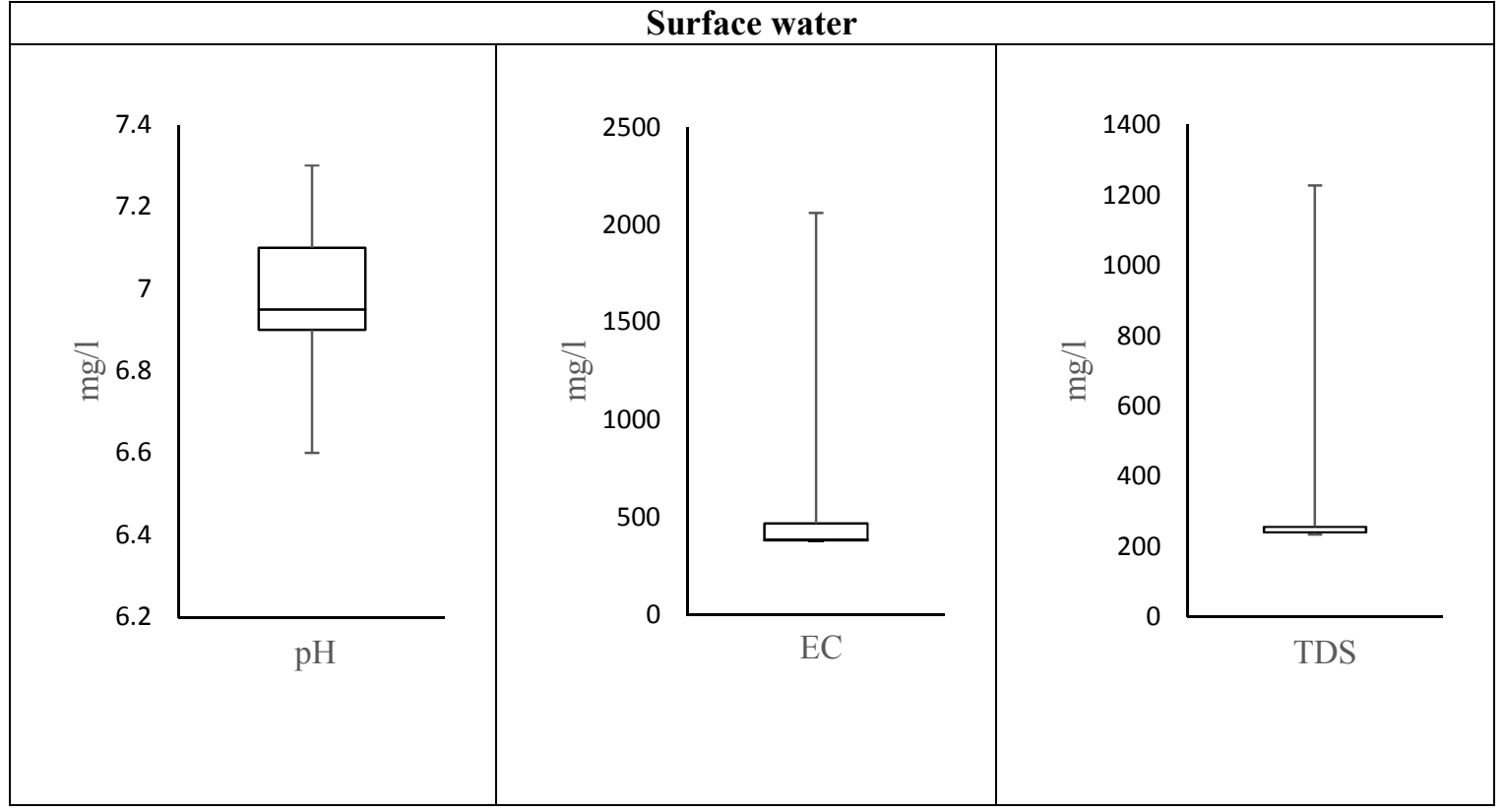

Fig. 7: Box plot for $\mathrm{pH}, \mathrm{EC}$ and TDS at the groundwater of the Quaternary and Miocene aquifer, Wadi El Tumilat area, Egypt.

\section{Hydrogeochemistry}

The groundwater chemistry is shown to be strongly related to the physical, chemical and mineralogical properties of the rock forming aquifer matrix, recharge and geochemical processes. The hydrogeochemistry of the Quaternary and Miocene aquifers will be discussed as following:

A- $\mathrm{pH}$ of Quaternary groundwater is varying between 6.7 and 7.9 with an average value of 7.2, while $\mathrm{PH}$ of at the Miocene groundwater, values range from 6.7 to 7.2 with an average value of 7.1, reflecting a neutral water (Fig. 7).

B- Total dissolved solids (TDS) of Quaternary groundwater ranges from 194.8 (well No. 61) to $4916.4 \mathrm{mg} / 1$ (well No. 42), with an average value of $2586 \mathrm{mg} / \mathrm{l}$ and a median of $2760.5 \mathrm{mg} / 1$ (Fig. 7). The groundwater salinity is fresh (TDS $<1500 \mathrm{mg} / \mathrm{l}$ ) at about $19 \%$ of samples, brackish (TDS $1500-5000 \mathrm{mg} / \mathrm{l}$ ) at about $65.1 \%$ and saline (TDS $>5000 \mathrm{mg} / \mathrm{l}$ ) at $15.9 \%$ of samples. The TDS values of the Miocene groundwater range from $5379.8 \mathrm{mg} / 1$ (well No. 13) to $6407.6 \mathrm{mg} / \mathrm{l}$ (well No. 14) showing saline water category.

C- The order of cations dominance in the Quaternary groundwater at the study area are $\mathrm{Na}^{+}+\mathrm{K}^{+}>$ $\mathrm{Ca}^{2+}>\mathrm{Mg}^{2+}$, while the order of anions are $\mathrm{Cl}^{-}>\mathrm{HCO}_{3}{ }^{-}+\mathrm{CO}_{3}{ }^{2-}>\mathrm{SO}_{4}{ }^{2-}$. At the Miocene groundwater, the order of cations dominance are $\mathrm{Na}^{+} \& \mathrm{~K}^{+}>\mathrm{Ca}^{2+}>\mathrm{Mg}^{2+}$, while the order of anions are $\mathrm{Cl}^{-}>\mathrm{SO}_{4}{ }^{2-}>\mathrm{HCO}_{3}{ }^{-}$.

D- In order to determine the water type, all constituents which are below a certain limit (10\%) are removed. $73.1 \%$ of samples have $\mathrm{Na}-\mathrm{Cl}$ water type, while $17.3 \%$ of samples have $\mathrm{Ca}(\mathrm{Na})-\mathrm{HCO}_{3}$ 
indicating meteoric water origin due to recharge from surface water canals. The third dominant water type is $\mathrm{Na}_{-} \mathrm{SO}_{4}$, which represent $9.6 \%$ of samples and reflecting the dissolution of terrestrial salts. The main water type at Miocene groundwater is $\mathrm{Na}-\mathrm{Cl}$ which may be revealed to leaching and dissolution of marine salts.

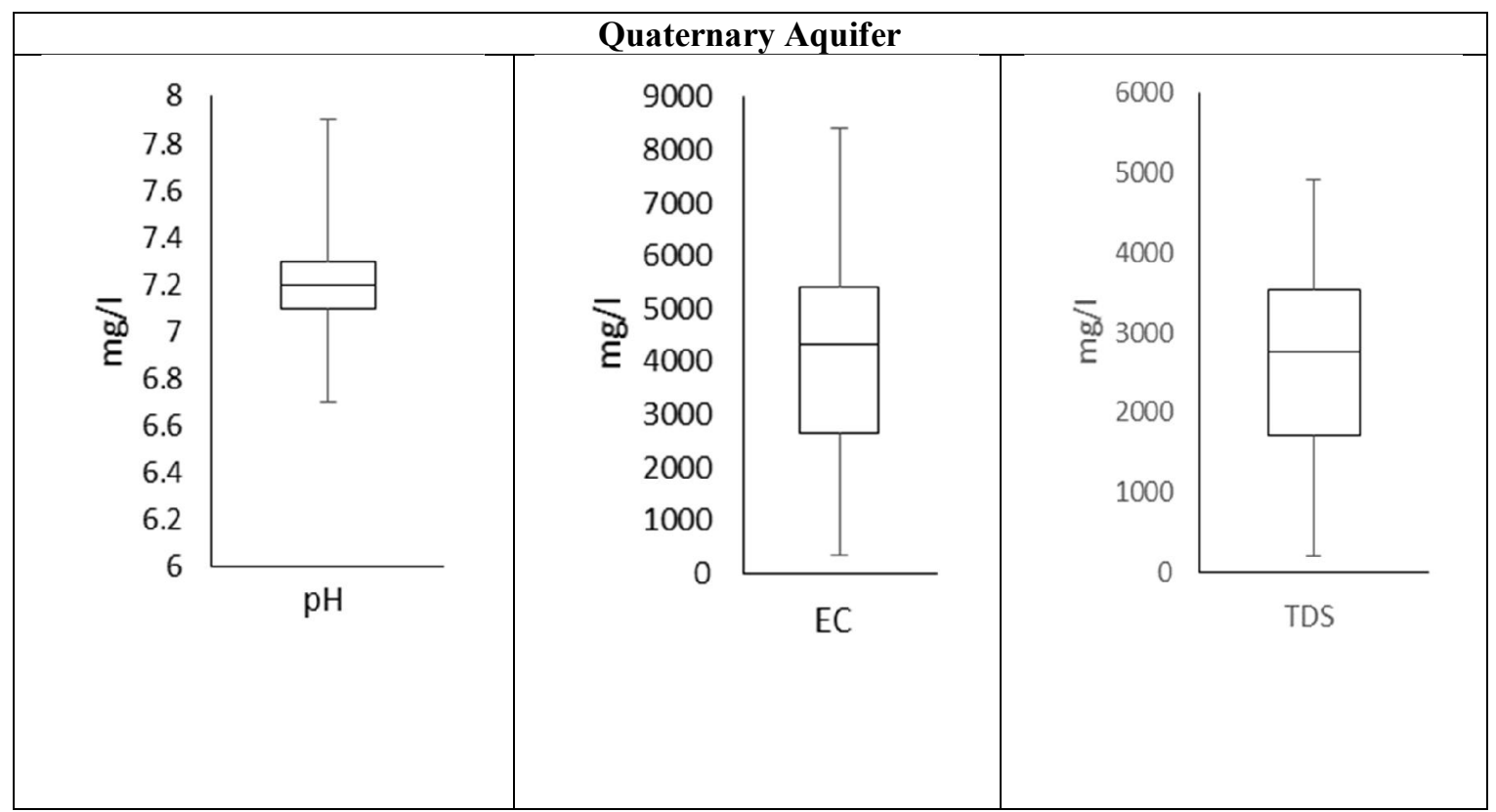

Fig. 8: Box plot of $\mathrm{Na}^{+}$and $\mathrm{K}^{+}$at the groundwater of the Quaternary and Miocene aquifer, Wadi El Tumilat area, Egypt.

\section{Major ions content in the groundwater}

Number of samples collected from the Miocene aquifer is small and their geographical distribution in the study area is limited, so the discussion of the next topics will be focused mainly on the hydrogeochemical aspects of the Quaternary aquifer.

\section{Sodium and potassium}

$\mathrm{Na}^{+}$and $\mathrm{K}^{+}$ions are the dominant cations in the Quaternary groundwater at Wadi El Tumilat ( $70 \%$ of total cations). $\mathrm{Na}^{+}$concentration ranges from $27 \mathrm{mg} / \mathrm{l}$ (well No. 61) to $1520 \mathrm{mg} / \mathrm{l}$ (well No. 6) with an average value of $742 \mathrm{mg} / \mathrm{l}$, and a median of $800 \mathrm{mg} / \mathrm{l}$. K ${ }^{+}$concentration ranges between 0.76 $\mathrm{mg} / \mathrm{l}$ (well No. 35) and $19.8 \mathrm{mg} / \mathrm{l}$ (well No. 5) with an average value of $7.9 \mathrm{mg} / \mathrm{l}$, and a median of 6.4 mg/l (Fig. 9).

The original source of $\mathrm{Na}^{+}$and $\mathrm{K}^{+}$ions are the dissolution of halite $(\mathrm{NaCl})$ and sylvite $(\mathrm{KCl})$ minerals. The hydrochemical coefficients $\mathrm{Na}^{+} / \mathrm{Cl}^{-}$and $\mathrm{Na}^{+}+\mathrm{K}^{+} / \mathrm{Cl}^{-}$have values more than 1 in $97 \%$ of samples, $\mathrm{Na}^{+} /\left(\mathrm{Na}^{+}+\mathrm{Cl}^{-}\right)$and $\left(\mathrm{Na}^{+}+\mathrm{K}^{+}\right) /\left(\mathrm{Na}^{+}+\mathrm{Cl}^{-}\right)$have values more than 0.5 (Hounslow, 1995), (Table.2). These entire ratios indicate that there are another sources of $\mathrm{Na}^{+}$and $\mathrm{K}^{+}$. These other sources of $\mathrm{Na}^{+}$and $\mathrm{K}^{+}$ions could be the silicate weathering and direct cation exchange. In the study area, the depletion of $\mathrm{K}^{+}$concentration in groundwater of the Quaternary aquifer may be either due to the low amount of potassium in the sediments or the adsorption of $\mathrm{K}^{+}$by clay minerals such as Smectite, montmorillonite and illite present within the Quaternary aquifer matrix (Mabrouk et al., 2016). 


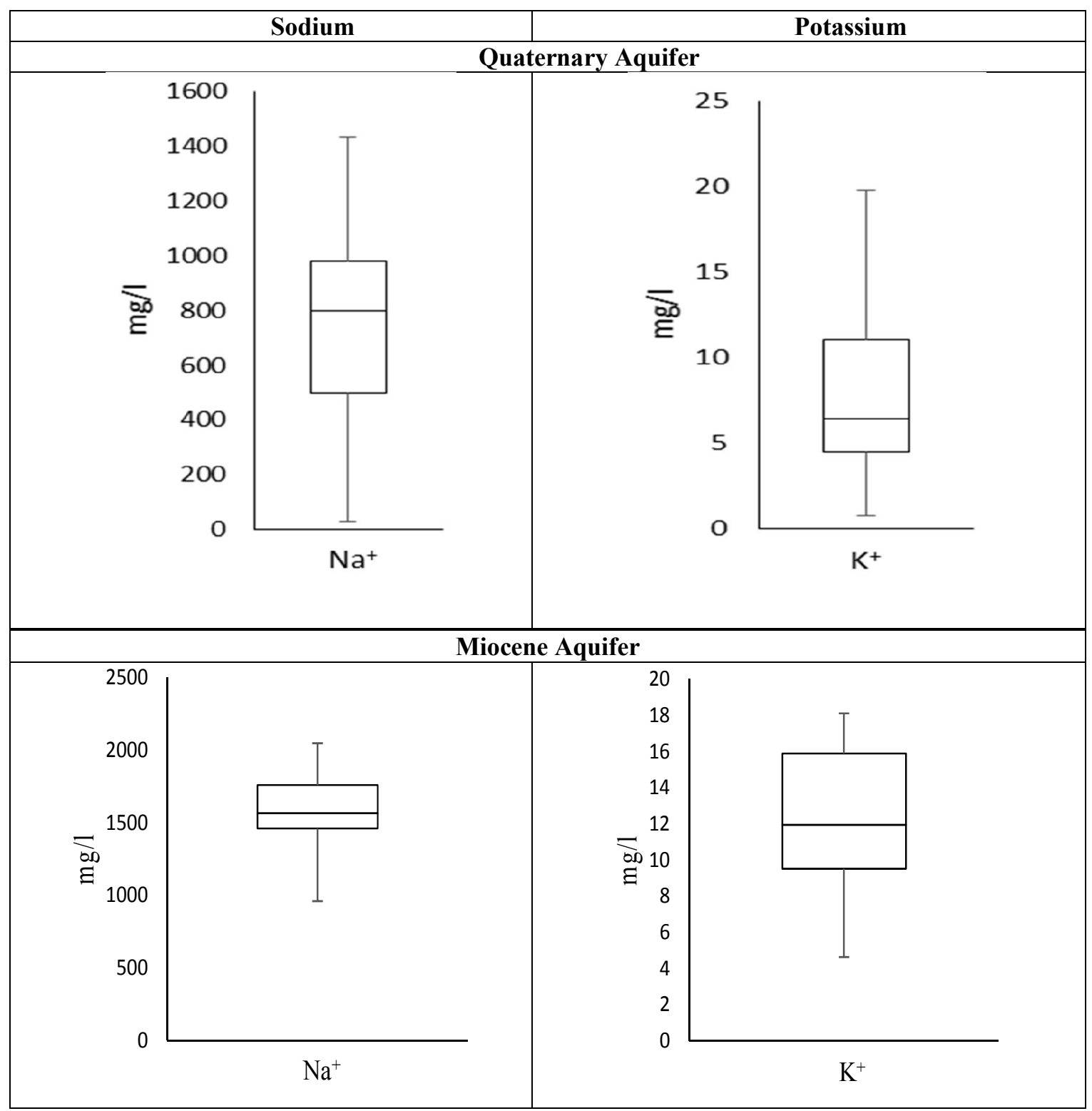

Fig. 9: Box plot of $\mathrm{Ca}^{2+}$ and $\mathrm{Mg}^{2+}$ in the Quaternary and Miocene groundwater of Wadi El Tumilat area, Egypt (2017).

\section{Calcium and magnesium}

$\mathrm{Ca}^{2+}$ and $\mathrm{Mg}^{2+}$ ions are dominated in the groundwater of Quaternary aquifer at Wadi El Tumilat area. They represent $30 \%$ of total cations $\left(\mathrm{Ca}^{2+}\right.$ and $\mathrm{Mg}^{2+}$ concentrations represent $20 \%$ \& $10 \%$ of total cations, respectively). $\mathrm{Ca}^{2+}$ concentration ranges from $24 \mathrm{mg} / \mathrm{l}$ (well No. 18) to $458 \mathrm{mg} / \mathrm{l}$ (well No. 6) with an average value of $158 \mathrm{mg} / \mathrm{l}$, and a median of $152 \mathrm{mg} / \mathrm{l}$, while $\mathrm{Mg}^{2+}$ concentration ranges from $3.9 \mathrm{mg} / \mathrm{l}$ (well No. 20) to $159 \mathrm{mg} / \mathrm{l}$ (well No. 6) with an average value of $52 \mathrm{mg} / \mathrm{l}$ and a median of $47 \mathrm{mg} / \mathrm{l}$ (Fig. 10).

The original sources of $\mathrm{Ca}^{2+}$ and $\mathrm{Mg}^{2+}$ are dissolution of carbonate minerals such as calcite $\left(\mathrm{CaCO}_{3}\right)$, magnesite $\left(\mathrm{MgCO}_{3}\right)$ and dolomite $\left(\mathrm{Ca}, \mathrm{Mg}\left(\mathrm{CO}_{3}\right)_{2}\right.$ beside evaporites as gypsum $\left(\mathrm{CaSO}_{4}\right.$. $\left.2 \mathrm{H}_{2} \mathrm{O}\right)$, anhydrite $\left(\mathrm{CaSO}_{4}\right)$.

$\mathrm{CaCO}_{3}$ (Calcite) $+\mathrm{H}_{2} \mathrm{CO}_{3} \rightarrow \mathrm{Ca}^{2+}+2 \mathrm{HCO}_{3}^{-}$

$\mathrm{Ca}, \mathrm{Mg}\left(\mathrm{CO}_{3}\right)_{2}$ (Dolomite) $+\mathrm{H}_{2} \mathrm{CO}_{3} \rightarrow \mathrm{Ca}^{2+}+\mathrm{Mg}^{2+}+4 \mathrm{HCO}_{3}$ 
The increasing concentration of $\mathrm{Ca}^{2+} \& \mathrm{Mg}^{2+}$ ions in the groundwater of the Quaternary aquifer at Wadi El Tumilat area is revealed the hydrochemical coefficients $\mathrm{Ca}^{2+} / \mathrm{Mg}^{2+}, \mathrm{Ca}^{2+} / \mathrm{SO}_{4}{ }^{2-}, \mathrm{Ca}^{2+} / \mathrm{HCO}_{3}{ }^{-}$ , $\mathrm{Ca}^{2+} / \mathrm{Ca}^{2+}+\mathrm{SO}_{4}{ }^{2+}$ and $\mathrm{Ca}^{2+} /\left(\mathrm{HCO}_{3}{ }^{-}+\mathrm{SO}_{4}{ }^{2-}\right)$, (Table 2). Such coefficients show that there is other source of $\mathrm{Ca}^{2+} \& \mathrm{Mg}^{2+}$ the dissolution of carbonates and evaporites. The other source of increasing $\mathrm{Ca}^{2+}$ and $\mathrm{Mg}^{2+}$ at the groundwater of the Quaternary aquifer is the cation exchange. The ratio $\mathrm{Ca}^{2+} / \mathrm{Ca}^{2+}+\mathrm{SO}_{4}{ }^{2+}$, as an example, if its value equal 0.5 it indicates gypsum dissolution and if its value is less than 0.5 , it indicates calcium removal by ion exchange or calcite precipitation (Hounslow, 1995).

Table 2: Range and mean of some ionic ratios in the Quaternary groundwater, Wadi El Tumilat area, Egypt (2017).

\begin{tabular}{|c|c|c|c|c|}
\hline & Factor & Min. & Max. & Mean \\
\hline 1. & $\mathrm{Na}^{+} / \mathrm{Cl}^{-}$in $\mathrm{meq} / 1$ & 0.99 & 9.93 & 1.89 \\
\hline 2. & $\mathrm{Na}^{+}+\mathrm{k}^{+} / \mathrm{Cl}^{-}$ & 1.0 & 10.65 & 2.07 \\
\hline 3. & $\mathrm{Na}^{+} /\left(\mathrm{Na}^{+}+\mathrm{Cl}^{-}\right)$ & 0.49 & 0.91 & 0.62 \\
\hline 4. & $\left(\mathrm{Na}^{+}+\mathrm{K}^{+}\right) /\left(\mathrm{Na}^{+}+\mathrm{Cl}^{-}\right)$ & 0.50 & 0.98 & 0.63 \\
\hline 5. & $\mathrm{Ca}^{2+} / \mathrm{Mg}^{2+}$ in $\mathrm{meq} / \mathrm{L}$ & 1.19 & 4.95 & 2.01 \\
\hline 6. & $\mathrm{Ca}^{2+} / \mathrm{SO}^{2-}$ in $\mathrm{meq} / \mathrm{L}$ & 0.27 & 4.99 & 0.87 \\
\hline 8. & $\mathrm{Ca}^{2+} / \mathrm{Ca}^{2+}+\mathrm{SO}_{4}{ }^{2+}$ & 0.22 & 0.83 & 0.40 \\
\hline 9. & $\mathrm{Ca} /\left(\mathrm{HCO}_{3}+\mathrm{SO}_{4}\right)$ in $\mathrm{meq} / \mathrm{L}$ & 0.13 & 0.65 & 0.39 \\
\hline 10. & $\mathrm{Mg}^{2+} / \mathrm{Cl}^{-}$ & 0.06 & 4.69 & 0.46 \\
\hline 11. & $\mathrm{Ca}^{2+} / \mathrm{Cl}^{-}$ & 0.16 & 7.26 & 0.87 \\
\hline 12. & $\mathrm{SO}_{4}{ }^{2-} / \mathrm{Cl}^{-}$ & 0.24 & 2.42 & 0.78 \\
\hline 16. 4 & $\mathrm{Ca} / \mathrm{Na} \mathrm{mmol} / \mathrm{l}$ & 0.04 & 1.00 & 0.19 \\
\hline 17. 4 & $\mathrm{HCO}_{3} / \mathrm{Na} \mathrm{mmol} / \mathrm{l}$ & 0.02 & 2.75 & 0.43 \\
\hline
\end{tabular}

\section{Bicarbonate, sulfate and chloride}

The bicarbonate concentration represents $24 \%$ of total anions and it ranges from $103.7 \mathrm{mg} / \mathrm{l}$ (well No. 5) to $958 \mathrm{mg} / \mathrm{l}$ (well No. 51) with an average value of $395.9 \mathrm{mg} / \mathrm{l}$ and a median of 396.5 $\mathrm{mg} / \mathrm{l}$. Sulfate represent $29 \%$ of total anions and ranges from $16 \mathrm{mg} / \mathrm{l}$ (well No. 61) to $1357 \mathrm{mg} / \mathrm{l}$ (well No. 57) with mean value of $620 \mathrm{mg} / \mathrm{l}$ and a median of $606 \mathrm{mg} / \mathrm{l}$. Chloride is widely distributed in the Quaternary groundwater in Wadi El Tumilat area where it represents $47 \%$ of total anions. Chloride concentration ranges from $6.3 \mathrm{mg} / \mathrm{l}$ (well No. 18) to $2832 \mathrm{mg} / 1$ (well No. 6) with an average value of $841 \mathrm{mg} / \mathrm{l}$ and a median $832 \mathrm{mg} / \mathrm{l}$ (Fig. 11). The order of anions dominance is $\mathrm{Cl}^{-}>\mathrm{SO}_{4}{ }^{2-}>\mathrm{HCO}_{3}{ }^{-}$.

The hydrochemical coefficients $\left(\mathrm{Na}^{+} / \mathrm{Cl}^{-}, \mathrm{Mg}^{2+} / \mathrm{Cl}^{-}, \mathrm{Ca}^{2+} / \mathrm{Cl}^{-}, \mathrm{SO}_{4}{ }^{2-} / \mathrm{Cl}^{-}\right.$and $\mathrm{HCO}_{3} / \mathrm{Cl}^{-}$, reveal the enrichment of chlorides in the groundwater of Wadi El Tumilat area (Table. 2). Revelle (1941) coefficient $\left(\mathrm{Cl}^{-} / \mathrm{HCO}_{3}{ }^{-}+\mathrm{CO}_{3}{ }^{2-}\right.$, in meq/l) ranges from 0.05 to 16.72 with an average value of 4.64 (see Table. 2) indicating injuriously contaminated water by anthropogenic sources as agricultural activity, or other sources such as hydrolysis or sewage contamination (Todd, 1959).

\section{Hydrogeochemical processes affecting the investigated groundwater quality: \\ Ion exchange}

The chloro-alkaline indices $\left(\mathrm{CAI} 1=\mathrm{Cl}^{-}-\left(\mathrm{Na}^{+}+\mathrm{K}^{+}\right) / \mathrm{Cl}^{-}, \mathrm{CAI} 2=\mathrm{Cl}-\left(\mathrm{Na}^{+}+\mathrm{K}^{+}\right) / \mathrm{SO}_{4}{ }^{2-}+\mathrm{HCO}_{3}{ }^{-}\right.$ $+\mathrm{CO}_{3}{ }^{2-}+\mathrm{NO}_{3}{ }^{-}$in meq/l) have negative values, (Fig. 11), (Schoeller, 1967). Negative values mean that the ion exchange is reverse (indirect), i.e., such ion exchange process includes $\mathrm{Na}^{+}$enrichment and depletion of $\mathrm{Ca}^{2+} \& \mathrm{Mg}^{2+}$ as follows:

$$
2 \mathrm{Na} \text { (clay) }+\mathrm{Ca}^{2+} \& \mathrm{Mg}^{2+}{ }_{\text {(aq.) }} \rightarrow \mathrm{Ca} \& \mathrm{Mg} \text { (clay) }+2 \mathrm{Na}^{+} \text {(aq.) }
$$

Mabrouk et al., (2016) determined the mineralogical composition of clay minerals encountered at the Quaternary aquifer of El Salhia area. They stated that the identified clay minerals include: 
Smectite, Kaolinite and Illite where Smectite is most predominant followed by Kaolinite and then by Illite. These clay minerals act as the solid surfaces at which the exchangeable ions are attached.

Another evidence for ion exchange is given by bivariate plots of $\mathrm{Ca}^{2+}+\mathrm{Mg}^{2+}-\left(\mathrm{HCO}_{3}{ }^{-}+\mathrm{SO}_{4}{ }^{2-}\right)$ as a function of $\mathrm{Na}^{+}+\mathrm{K}^{+}-\mathrm{Cl}^{-}$(Fig. 13). If cation exchange was an important composition-controlling process, the relation between these two parameters would be linear with a slope of -1 (Mclean et al., 2000). This is the case for the groundwater samples collected from the Quaternary aquifer where the majority of samples are ploted close to a straight line $\left(r^{2}=0.88\right)$ with a slope of -0.89 .

\section{Silicate weathering}

The dissolution of silicate minerals can be another source of increasing $\left(\mathrm{Na}^{+} \& \mathrm{~K}^{+}\right)$as shown from the relations of $\mathrm{Ca}^{2+} / \mathrm{Na}^{+}$vs. $\mathrm{HCO}_{3}{ }^{-} \mathrm{Na}^{+}$and $\mathrm{Ca}^{2+} / \mathrm{Na}^{+}$vs. $\mathrm{Mg}^{2+} / \mathrm{Na}^{+}$(as molar ratios). All samples show increase of $\mathrm{Na}$ than $\mathrm{Ca}$, while $88 \%$ of total samples (51 sample) show an increase of $\mathrm{Na}$ than $\mathrm{HCO}_{3}$ due to silicate weathering beside ion exchange which leads to the increase of $\mathrm{Na}^{+}$. On the other hand, $12 \%$ of water samples collected from the Quaternary aquifer ( 7 samples) show an increase of $\mathrm{HCO}_{3}{ }^{-}$than $\mathrm{Na}^{+}$may be due to evaporites dissolution (Fig. 14a). Furthermore, (Fig. 13b) declared that all samples have an increase of $\mathrm{Na}^{+}$than $\mathrm{Ca}^{2+}$ and $\mathrm{Mg}^{2+}$ due to the higher solubility of $\mathrm{Na}^{+}$ relative to $\mathrm{Ca}^{2+}$ and $\mathrm{Mg}^{2+}$, so lower $\mathrm{Ca}^{2+} / \mathrm{Na}^{+}$and $\mathrm{Mg}^{2+} / \mathrm{Na}^{+}$(as molar ratios) are expected in the investigated groundwater due to silicate weathering (Hounslow, 1995).

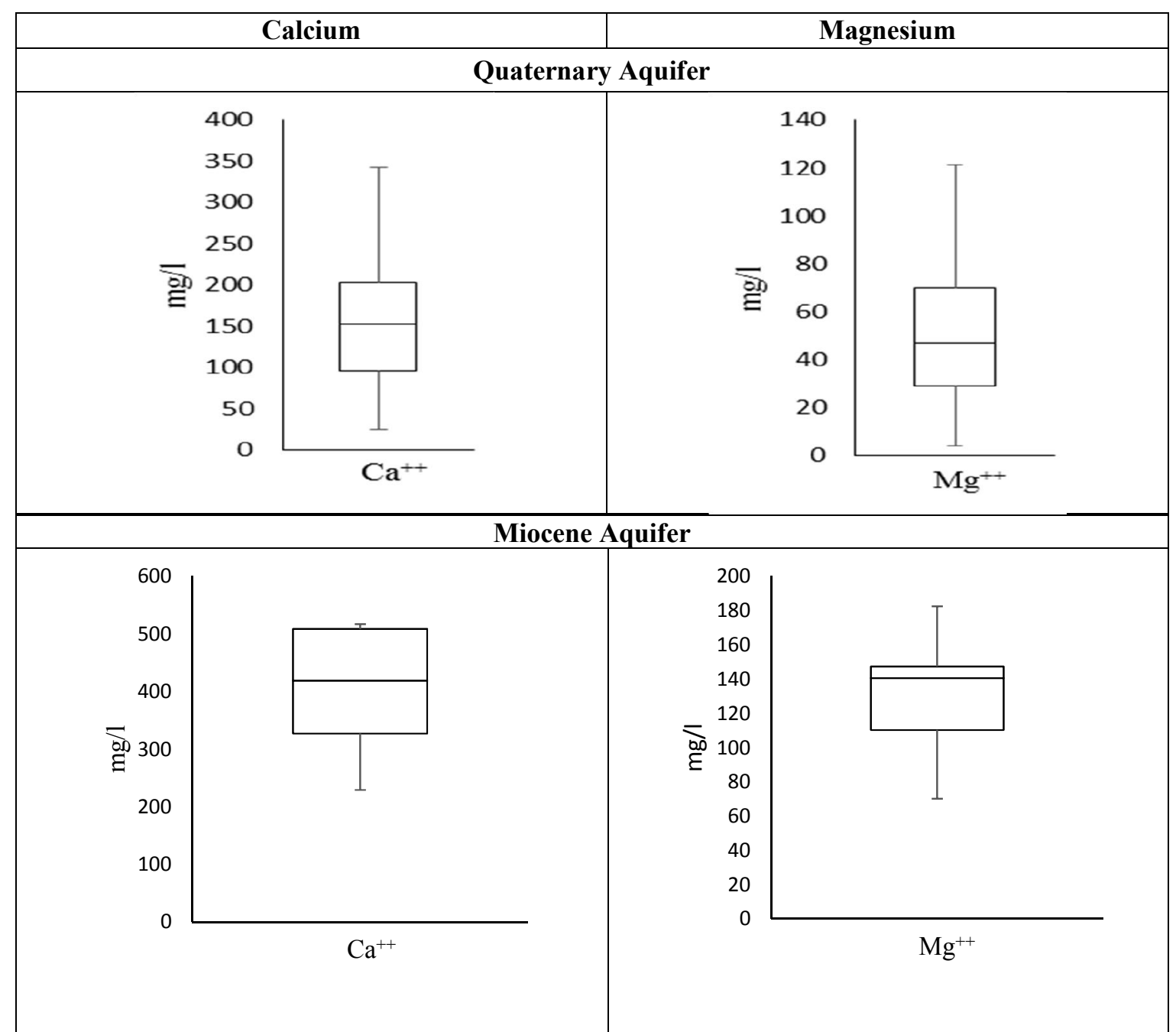

Fig. 10: Box plot of $\mathrm{HCO}_{3}^{-}, \mathrm{SO}_{4}{ }^{2-}$ and $\mathrm{Cl}^{-}$in the Quaternary and Miocene groundwater of Wadi $\mathrm{El}$ Tumilat area, Egypt (2017). 


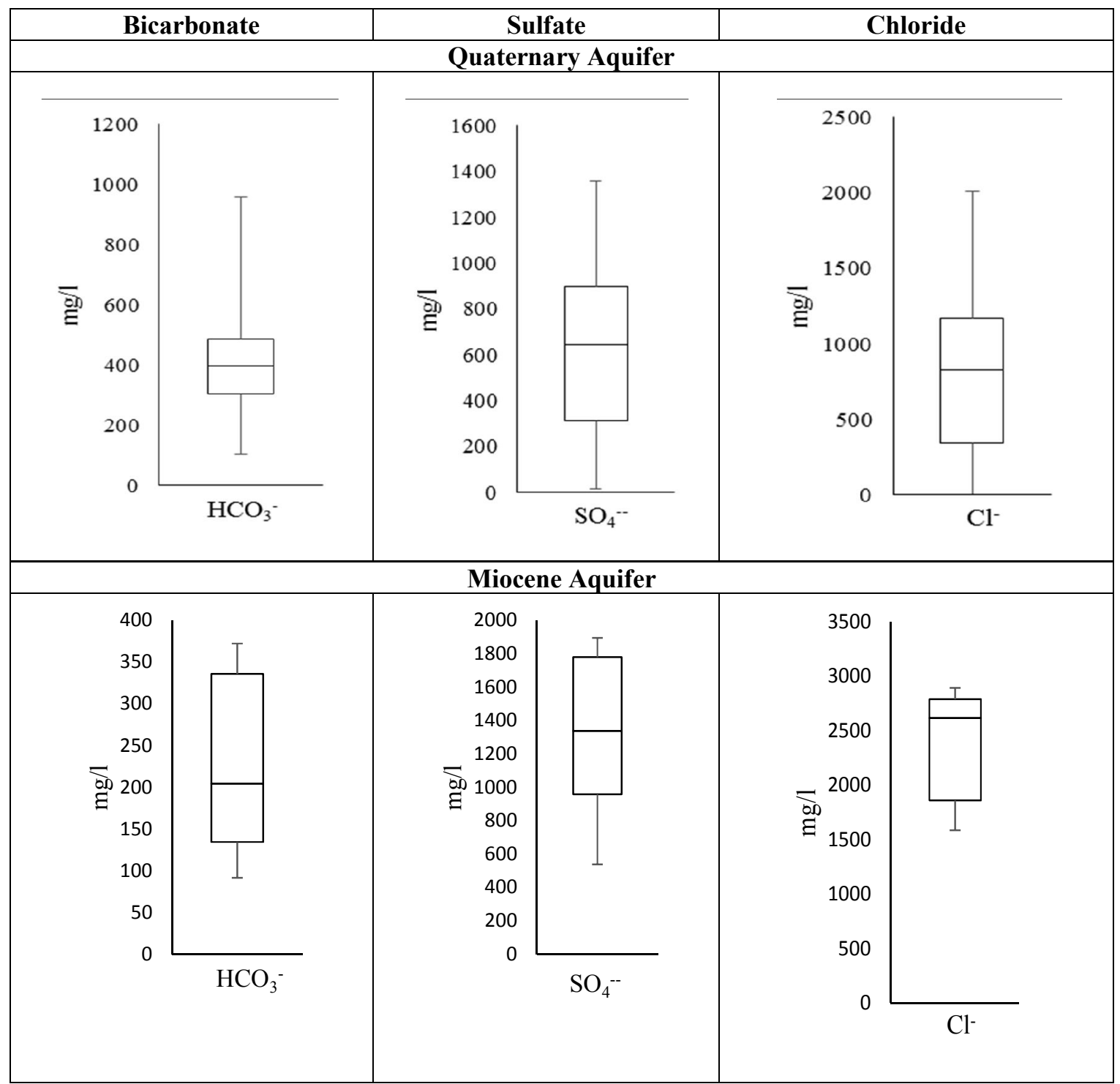

Fig. 11: Box plot of $\mathrm{HCO}_{3}{ }^{-}, \mathrm{SO}_{4}{ }^{2-}$ and $\mathrm{Cl}^{-}$in the Quaternary and Miocene groundwater of Wadi $\mathrm{El}$ Tumilat area, Egypt (2017).

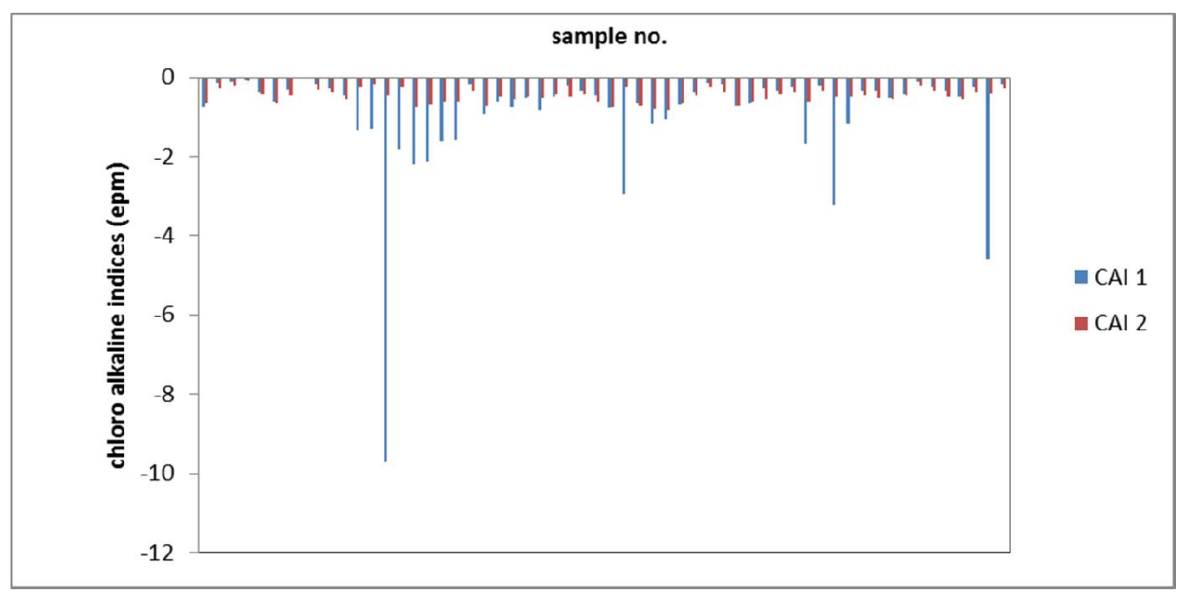

Fig. 12: Bar diagram of the chloro-alkaline indices for the Quaternary aquifer at Wadi El Tumilat area, Egypt 


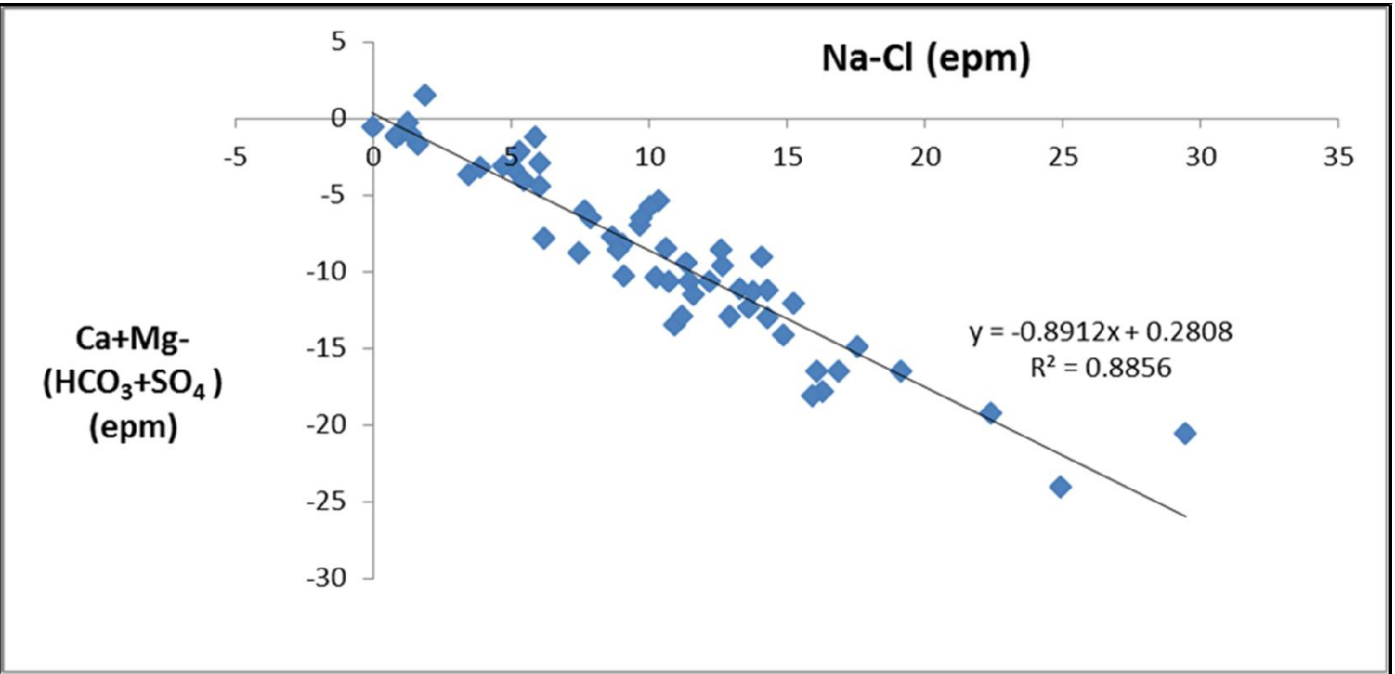

Fig. 13: Scatter diagram of $(\mathrm{Ca}+\mathrm{Mg})-\left(\mathrm{HCO}_{3}+\mathrm{SO}_{4}\right)$ vs. $(\mathrm{Na}+\mathrm{k}-\mathrm{Cl})$ for the Quaternary groundwater samples collected from Wadi El Tumilat area, Egypt.

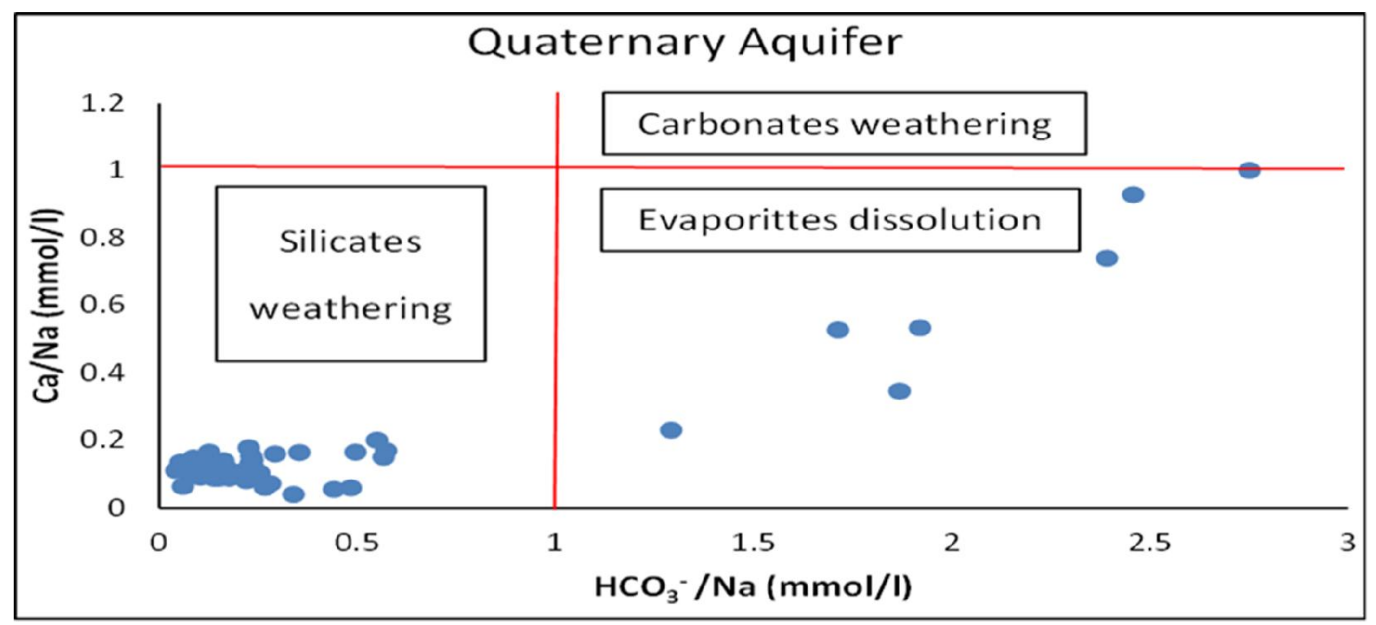

Fig. 14a: Scatter diagram of $\mathrm{Ca}^{2+} / \mathrm{Na}^{+}$vs. $\mathrm{HCO}_{3}{ }^{-} / \mathrm{Na}^{+}(\mathrm{mmol} / \mathrm{l})$ for the Quaternary groundwater samples collected from Wadi El Tumilat area, Egypt.

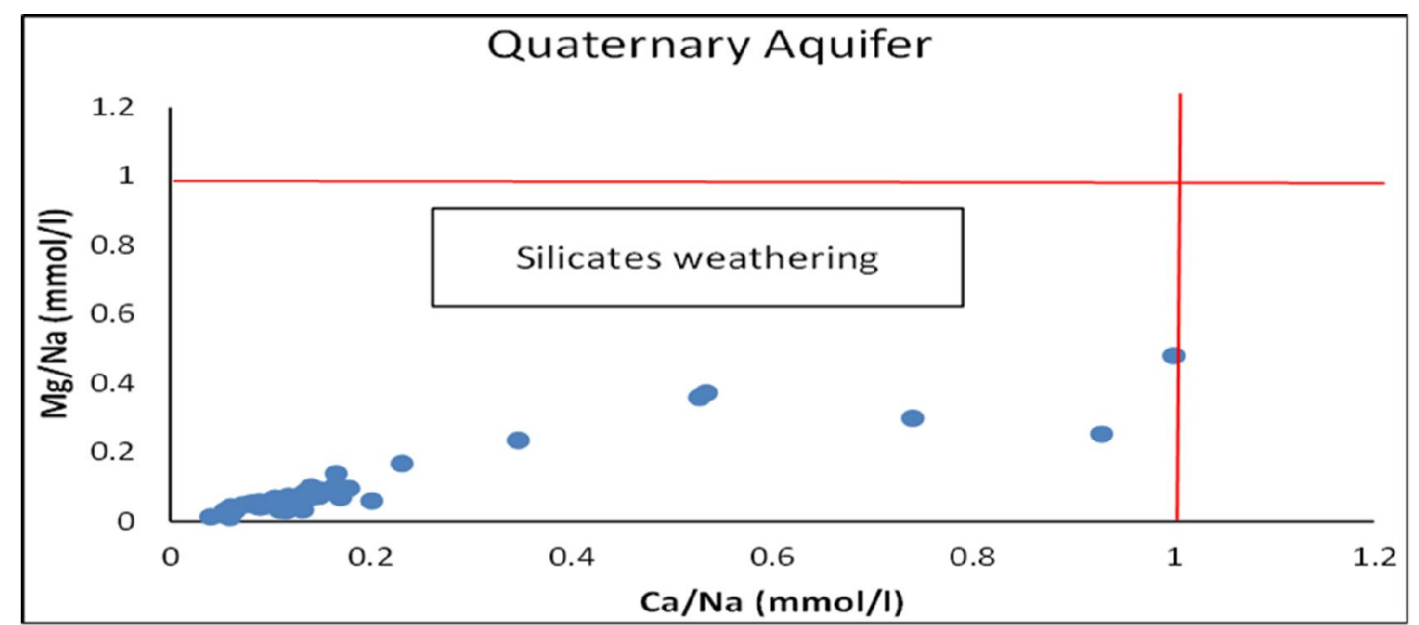

Fig. 14b: Scatter diagram of $\mathrm{Ca}^{2+} / \mathrm{Na}^{+}$vs. $\mathrm{Mg}^{2+} / \mathrm{Na}^{+}(\mathrm{mmol} / \mathrm{l})$ for the Quaternary groundwater samples collected from Wadi El Tumilat area, Egypt. 
Generally, $\mathrm{SO}_{4}{ }^{2-}$ concentration (as meq/l) in the groundwater of the Quaternary aquifer is more than $\mathrm{Ca}^{2+}$ concentration, so at the plot of $\mathrm{Ca}^{2+}$ vs. $\mathrm{SO}_{4}{ }^{2-}$ (Fig. 15), the data are plotted above 1:1 line (the gypsum line) with a little shift to left towards the $\mathrm{SO}_{4}$ vertical axis. This increase of $\mathrm{SO}_{4}{ }^{2-}$ in groundwater may be due to other processes than gypsum dissolution such as pyrite oxidation and/or anthropogenic sources such as waste water effluent and untreated industrial water, while the decrease of $\mathrm{Ca}^{2+}$ concentration in groundwater may be due calcite precipitation and/or ion exchange (Hounslow, 1995).

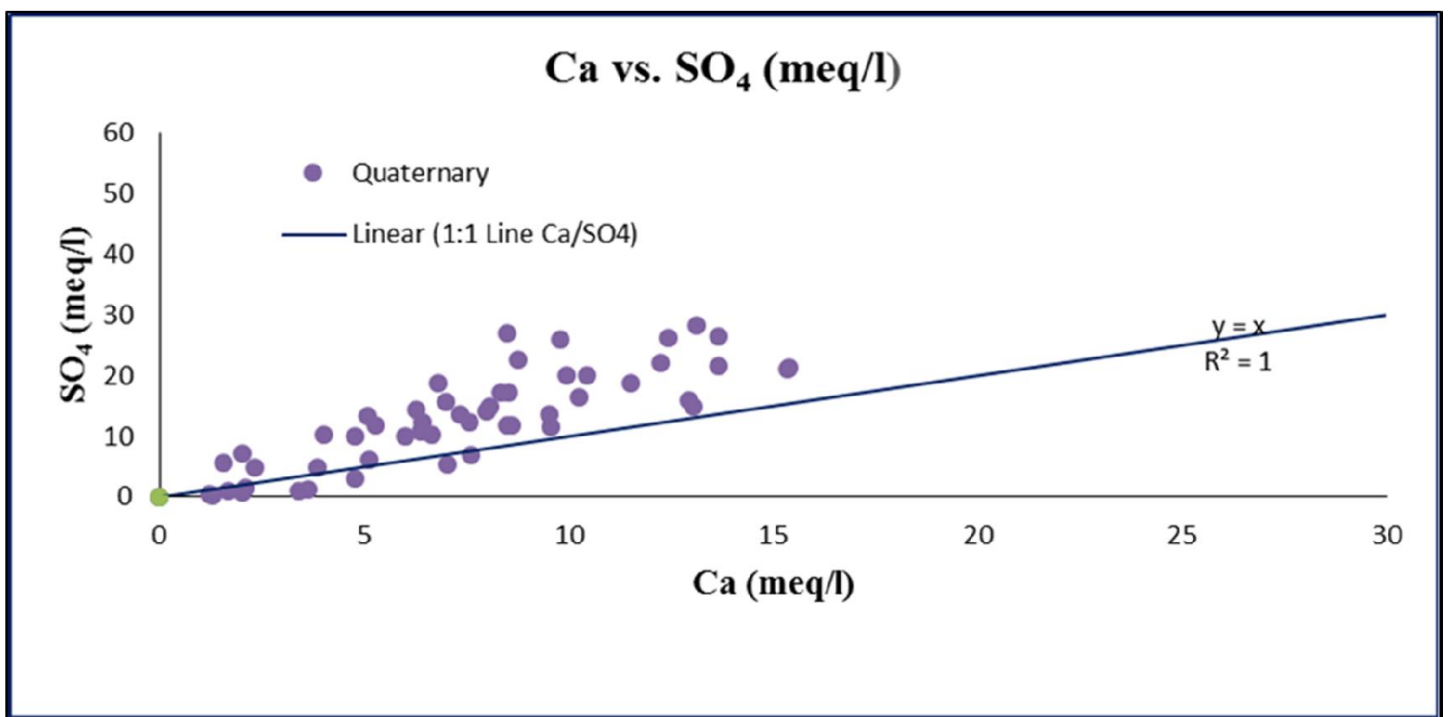

Fig. 15: Scatter diagram of $\mathrm{Ca}^{2+}$ vs. $\mathrm{SO}_{4}{ }^{2-}$ for the Quaternary groundwater samples collected from Wadi El Tumilat area, Egypt

Thirty nine samples (represent about $68 \%$ of total samples) have $\mathrm{Ca}^{2+} / \mathrm{Ca}^{2+}+\mathrm{SO}_{4}{ }^{2-}$ less than 0.5 (Fig. 16) due to calcium removal by ion exchange or calcite precipitation at $\mathrm{pH}$ equal 7 or pyrite oxidation at pH more than 5.5 (Hounslow, 1995). In turn, twenty seven samples (about 32\% of total samples) have this ratio more than 0.5 ; this means that there is another source of $\mathrm{Ca}^{2+}$ than gypsum dissolution as silicate or carbonate weathering (Hounslow, 1995).

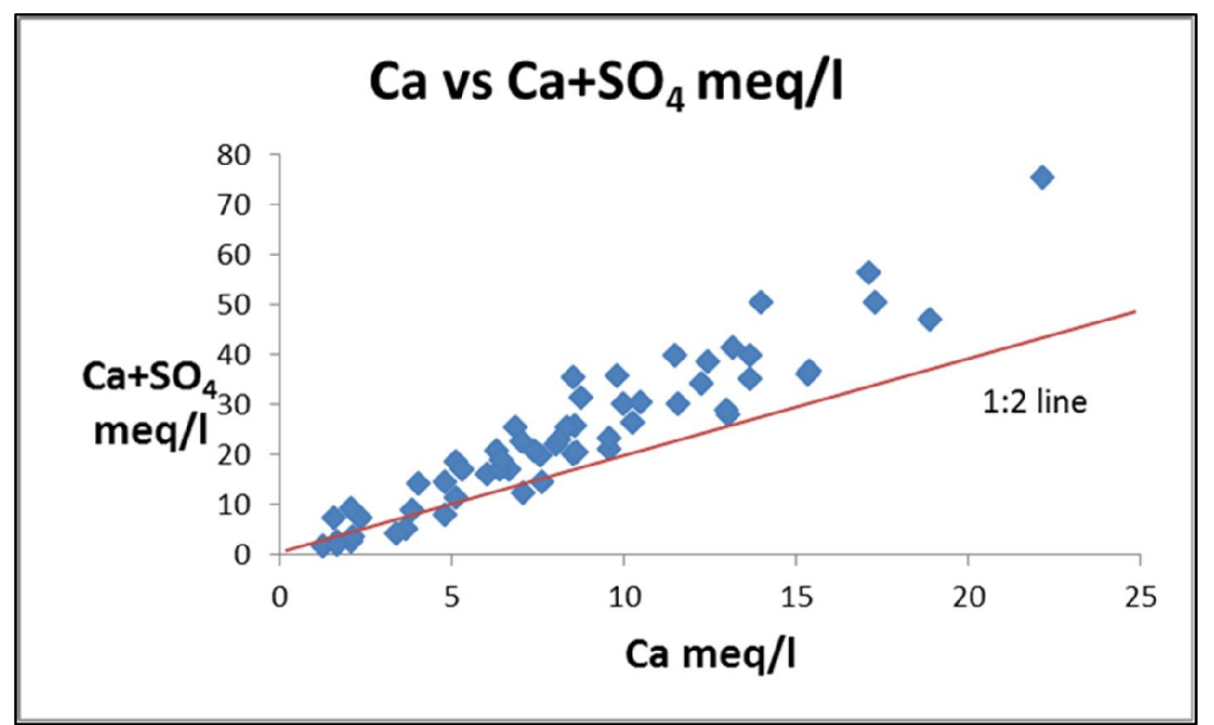

Fig. 16: Scatter diagram of $\mathrm{Ca}^{2+}$ vs. $\mathrm{Ca}^{2+}+\mathrm{SO}_{4}{ }^{2-}$ for the Quaternary groundwater samples collected from Wadi El Tumilat area, Egypt. 


\section{Evaporation}

Gibbs diagram (1970) has been constructed to show the hydrochemical processes affecting groundwater chemistry such as water-rock interactions, meteoric precipitation and evaporation. This diagram illustrates the influence of host rock on groundwater composition. TDS values (expressed as ppm) were plotted against the ratios $\left(\mathrm{Na}^{+}+\mathrm{K}^{+} / \mathrm{Na}^{+}+\mathrm{K}^{+}+\mathrm{Ca}^{2+}\right.$, expressed as epm) and $\left(\mathrm{Cl}^{-} / \mathrm{Cl}^{-}+\right.$ $\mathrm{HCO}_{3}{ }^{-}$, expressed as epm) in two separate plots (Fig. 17 a and b, respectively). The major ion chemistry together with Gibbs ratio plots indicate that, the investigated groundwater chemistry in Wadi El Tumilat area is mainly controlled by evaporation in addition to water-rock interactions because the annual rainfall and groundwater recharge of the area are insignificant, and temperature is high especially during most seasons of the year.

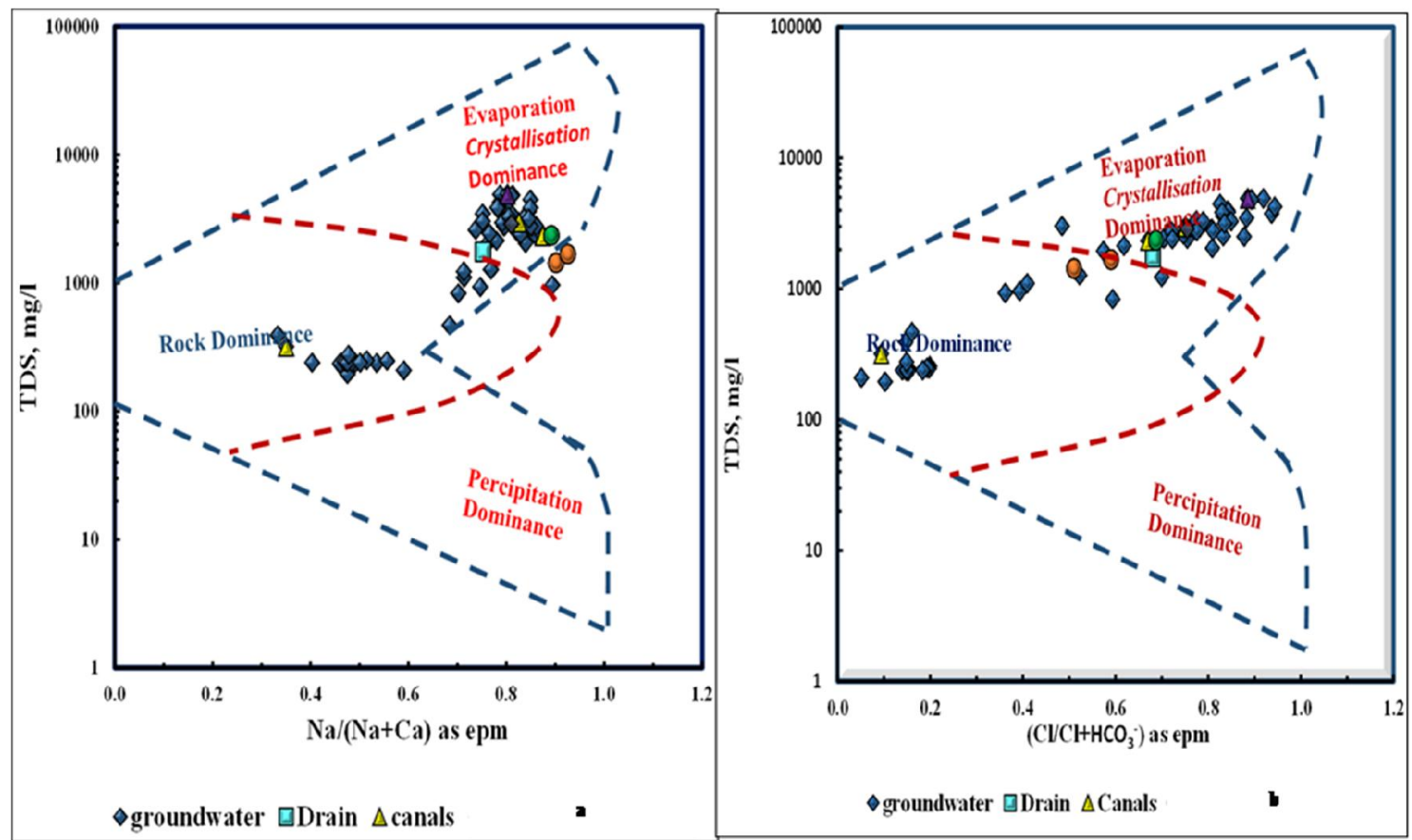

Fig. 17: Gibbs diagrams for the groundwater samples collected from the Quaternary aquifer, Wadi El Tumilat area, Egypt.

The $\mathrm{Na}^{+} / \mathrm{Cl}^{-}$ratio has been used to identify the mechanism for acquiring salinity and saline intrusions in semiarid or arid regions (Herczeg and Edmunds, 1999). The strong correlation between $\mathrm{Na}^{+}$and $\mathrm{Cl}^{-}\left(\mathrm{R}^{2}=0.93\right.$, Fig. 18), indicate that $\mathrm{Cl}^{-}$and $\mathrm{Na}^{+}$, are derived from dissolution of minerals rich in $\mathrm{Na}^{+}$and $\mathrm{Cl}^{-}$such as halite. A principal feature of the groundwater is the enrichment of $\mathrm{Na}^{+}$relative to $\mathrm{Cl}^{-} . \mathrm{Na} / \mathrm{Cl}$ ratios range from 9.937 in the most fresh water sample (well No.18) to 0.999 in one of the most saline water samples (well No.12). The $\mathrm{Na}^{+} / \mathrm{Cl}^{-}$ratios of almost all Quaternary water samples have values greater than unity probably because their chemistry is controlled by water-rock interactions (most likely by silicate weathering). The increase of this ratio than unity in the Quaternary aquifer reflects also the meteoric water origin of the recharge sources of the Quaternary aquifer (i.e., the surface water system especially El Ismalia canal). Only one sample (no. 12) has value of this ratio less than unity probably due to ion exchange of $\mathrm{Na}^{+}$for $\mathrm{Ca}^{2+}$ and $\mathrm{Mg}^{2+}$ on the surface of clays or other solid materials. The plot of $\mathrm{Na}^{+} / \mathrm{Cl}^{-}$values for most water samples of the Quaternary aquifer below the 1:1 line at Figure 17 indicate that the evaporation is not the major process controlling the groundwater chemistry at this aquifer, but also have a significant effect water-rock interactions, ion exchange and mixing. 


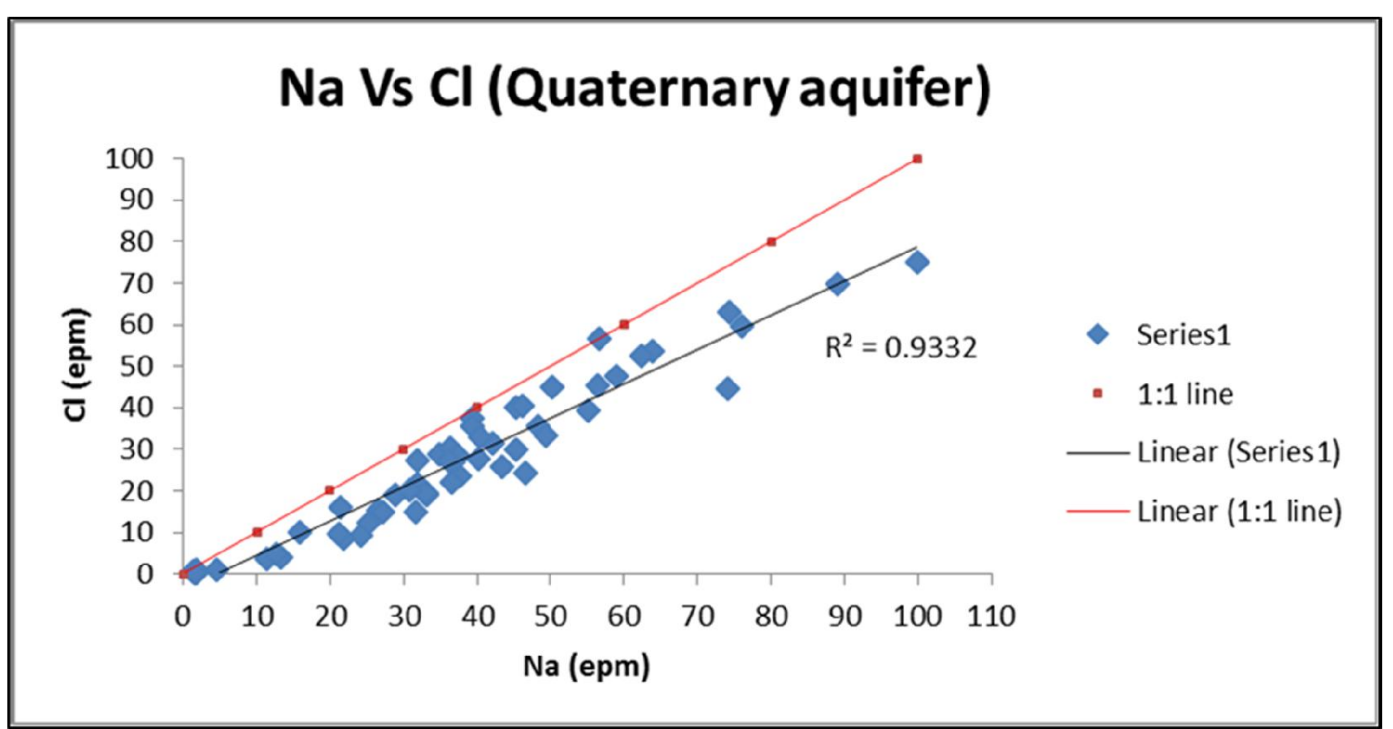

Fig. 18: Scatter diagram of $\mathrm{Na}^{2+}$ vs. $\mathrm{Cl}^{-}$for the Quaternary groundwater samples collected from Wadi Mixing

El Tumilat area, Egypt

The mixing process at Wadi El Tumilat area occurs either between surface and groundwater systems or between groundwaters of two different aquifers. The recharge of surface water (mainly from Ismailia canal) to Quaternary aquifer is a clear example of mixing between surface and groundwater systems which is demonstrated previously by the scatter diagram of $\mathrm{Na}^{+}$and $\mathrm{Cl}^{-}$. The relationship between surface and groundwater in the study area is strongly influenced by the canal or lake depth, height of the water Table relative to the surface water levels, type of sediments forming the bottom and banks of surface water canals, rate of horizontal and vertical hydraulic boundary conditions of the groundwater system and hydraulic conductivity of the Quaternary aquifer (Mabrouk, 2016).

The mixing between groundwaters of two different aquifers is illustrated by mixing between the Quaternary and the Miocene aquifers at the southern part of the study area (El Sayed, 2018). There is a limited recharge from the Miocene aquifer to the Quaternary aquifer at the northern part of study area (El Salhia locality) as proved from the isotopic study of (Gomaah et al., 2016).

\section{Statistical analysis results}

The current study comprises the application of multivariate statistical techniques such as correlation matrix analysis (CMA) and hierarchical cluster analysis (HCA) to analyze water quality data set obtained for groundwater samples collected from the study area. These statistical techniques provide a way to handle large data sets with large numbers of variables. Ten variables (TDS, $\mathrm{pH}$, $\mathrm{Ca}^{2+}, \mathrm{Mg}^{2+}, \mathrm{Na}^{+}, \mathrm{K}^{+}, \mathrm{HCO}_{3}{ }^{-}, \mathrm{CO}_{3}{ }^{-}, \mathrm{Cl}^{-}$, and $\mathrm{SO}_{4}{ }^{2-}$ ) were chosen for the present statistical study. Recent studies have confirmed the usefulness of multivariate analysis techniques for (i) evaluation and interpretation of groundwater quality data sets (Singh et al., 2009), (ii) providing insight into the processes that control the water composition (Ruiz et al., 1990 \& Papatheodorou et al., 2007), (iii) identifying possible sources of pollution/polluting processes (Singh et al., 2005, Kumar and Riyazuddin 2008), (iv) interaction of river water/groundwater and groundwater mixing (Reghunath et al., 2002 \& Mohapatra et al., 2011). The statistical analysis at the present study was performed using the Statistical Package for Social Sciences (SPSS) software, version 16.0 for windows.

\section{Correlation matrix analysis among the variables}

The relationships among the water chemistry variables of the Quaternary groundwater samples are shown by Pearson's rank correlation coefficient (r) matrix and the corresponding P value (Table. 3 ). The factors were extracted from a correlation matrix of the variables by the principal component analysis. Pearson's $r$ value varies between +1 and -1 , where +1 is a perfect positive correlation, and -1 is a perfect negative correlation. 0 means there is no linear correlation at all. Furthermore, when $r$ 
value become close to 1 or -1 , this means there is strong positive or negative correlation, respectively and as the $r$ value close to zero, this imply weak correlation. The term ( $p$ value) is used and introduced for the first time by Ronald Fisher in the 1920s because he wanted an objective method for comparing data to the null hypothesis. According to many statistic scientists P values are powerful tools but they need to be used and interpreted correctly.

Based on the previous concepts and referring to the $r$ and $p$ values of the Quaternary aquifer, a strong positive correlation was observed between TDS and $\mathrm{Ca}^{2+}, \mathrm{Mg}^{2+}, \mathrm{Na}^{+}, \mathrm{SO}_{4}{ }^{2-}, \mathrm{Cl}^{-}$and these variables are also positively correlated with each other. The $\mathrm{P}$ values are zeros (less than the significance level of 0.01 which is indicated by the two asterisks above the correlation coefficients, $r$ ). This means that these ions have a great influence on groundwater salinization of the Quaternary aquifer at Wadi El Tumilat area. The weak correlation between TDS and the carbonate species; $\mathrm{HCO}_{3}{ }^{-}$ and $\mathrm{CO}_{3}{ }^{2-}$ ( $\mathrm{r}=0.004$ and -0.027 , respectively and the corresponding $\mathrm{P}$ values are 0.976 and 0.801 , which is more than the significance levels of 0.01 and 0.05 ) may indicate the weak influence of $\mathrm{HCO}_{3}{ }^{-}$and $\mathrm{CO}_{3}{ }^{2-}$ on the groundwater mineralization in the Quaternary aquifer. $\mathrm{SO}_{4}{ }^{2-}$ and $\mathrm{Cl}^{-}$have strong correlation with $\mathrm{Ca}^{2+}, \mathrm{Mg}^{2+}$ and $\mathrm{Na}^{+}$( $\mathrm{r}$ values range from 0.829 to 0.966 and the $\mathrm{P}$ values are zeros), while they have weak correlation with $\mathrm{K}^{+}$(r values are 0.376 and 0.349 for $\mathrm{SO}_{4}{ }^{2-}$ and $\mathrm{Cl}^{-}$, respectively and the corresponding $\mathrm{P}$ values are 0.004 and 0.007 which are less than the significance level of 0.05 , i.e., the correlation is weak but it is statistically significant). There is also strong positive correlation between $\mathrm{Na}^{+}$and both of $\mathrm{Ca}^{2+}, \mathrm{Mg}^{2+}(\mathrm{r}=0.885$ and 0.817 , respectively and the corresponding $\mathrm{P}$ values are zeros, which is less than the significance level of 0.01 and this imply strong and significant correlation between sodium and these two alkaline earths). This may explain the dominance of cation exchange between these ions at the Quaternary aquifer environment.

Table 3: Pearson correlation matrix of the hydrochemical variables of the Quaternary aquifer, Wadi El Tumilat area, Egypt

\begin{tabular}{|c|c|c|c|c|c|c|c|c|c|c|c|}
\hline & pH & $\mathrm{EC}(\boldsymbol{\mu} \mathrm{S} / \mathrm{Cm})$ & TDS & $\mathrm{Ca}$ & Mg & $\mathrm{Na}$ & $\mathbf{K}$ & $\mathrm{CO}_{3}$ & $\mathrm{HCO}_{3}$ & $\mathrm{SO}_{4}$ & Cl \\
\hline pH & $*$ & & & & & & & & & & \\
\hline $\mathrm{EC}(\mu \mathrm{S} / \mathrm{Cm})$ & .002 & $*$ & & & & & & & & & \\
\hline TDS & .000 & $.990^{* *}$ & $*$ & & & & & & & & \\
\hline $\mathbf{C a}$ & -.061 & $.908^{* * *}$ & $.930^{* *}$ & $*$ & & & & & & & \\
\hline Mg & -.112 & $.848^{* *}$ & $.872^{* *}$ & $.937^{* * *}$ & $*$ & & & & & & \\
\hline $\mathrm{Na}$ & .026 & $.991^{* *}$ & $.992^{* *}$ & $.885^{* *}$ & $.817^{* *}$ & $*$ & & & & & \\
\hline $\mathbf{K}$ & .145 & $.361^{* *}$ & $.374^{* *}$ & $.296^{*}$ & $.307^{*}$ & $.354^{* *}$ & $*$ & & & & \\
\hline $\mathrm{CO}_{3}$ & $.499^{* *}$ & -.005 & -.027 & -.123 & -.110 & .000 & $.317^{*}$ & * & & & \\
\hline $\mathrm{HCO}_{3}$ & -.071 & .019 & .004 & -.052 & .037 & .028 & .092 & .056 & * & & \\
\hline $\mathrm{SO}_{4}$ & .001 & $.898^{* *}$ & $.944^{* *}$ & $.887^{* * *}$ & $.829^{* *}$ & $.921^{* *}$ & $.376^{* *}$ & -.037 & -.036 & $*$ & \\
\hline $\mathrm{Cl}$ & -.004 & $.981^{* *}$ & $.969^{* *}$ & $.903^{* *}$ & $.843^{* * *}$ & $.966^{* *}$ & $.349^{* *}$ & -.034 & -.079 & $.844^{* *}$ & * \\
\hline
\end{tabular}

For the Miocene groundwater samples, there is a strong negative correlation between $\mathrm{K}^{+}$and $\mathrm{Ca}^{2+}$, moderate negative correlation between $\mathrm{K}^{+}$and $\mathrm{TDS}, \mathrm{Cl}^{-}, \mathrm{HCO}_{3}^{-}, \mathrm{Mg}^{2+}$ as shown at the Pearson's correlation matrix and the corresponding $\mathrm{P}$ values (Table. 4). The underlined values at this Table are the statistically insignificant moderate and strong correlation coefficients). The $\mathrm{P}$ values accompanying for these correlation coefficients are $0.137,0.347,0.213,0.288$ and 0.309 for $\mathrm{Ca}^{+}$, TDS, $\mathrm{Cl}^{-}, \mathrm{HCO}_{3}{ }^{-}$and $\mathrm{Mg}^{2+}$, respectively. This means that these $\mathrm{P}$ values are greater than the common significance levels $(0.05$ and 0.01$)$ which imply that this strong and moderate correlation is not statistically significant. Furthermore, the other alkali metal $\left(\mathrm{Na}^{+}\right)$has strong and moderate positive correlation with the alkaline earths $\left(\mathrm{Ca}^{2+}, \mathrm{Mg}^{2+}\right.$, respectively), all these ions are encountered at the ion exchange process. The $\mathrm{P}$ values of this correlation are 0.098 and 0.216 for $\mathrm{Ca}^{2+}$ and $\mathrm{Mg}^{2+}$, respectively. Again, these $\mathrm{P}$ values are more than 0.05 and 0.01 which indicate that this correlation is insignificant. It is worthy to mention that, the correlation between alkali metals and alkaline earths is ranging from moderate to strong but based on the $\mathrm{P}$ values it is statistically insignificant which means that the ion exchange process is not dominant at the Miocene groundwater environment but it is dominant at the Quaternary aquifer environment. Similar to the Quaternary aquifer correlation matrix, there is a strong correlation between TDS and $\mathrm{Ca}^{2+}, \mathrm{Na}^{+}, \mathrm{Cl}^{-}$(the $\mathrm{r}$ values are $0.905,0.967$ and 0.887 , respectively and 
the corresponding $\mathrm{P}$ values are $0.034,0.007$ and 0.045 which are less than the significance level of 0.05 , i.e., the correlation is statistically significant) which again may indicate the important effect of these ions on the Miocene groundwater salinity (mineralization). Noteworthy that the strong positive correlation between TDS and both of $\mathrm{Mg}^{2+}$ and $\mathrm{SO}_{4}{ }^{2-}$ in the Quaternary groundwater is absent at the Miocene groundwater due to the effect of these ions on the salinity of the Miocene groundwater is weak.

Table 4: Pearson correlation matrix of the hydrochemical variables in the Miocene aquifer, Wadi El

\begin{tabular}{|c|c|c|c|c|c|c|c|c|c|c|c|}
\hline & pH & $\mathrm{EC}(\mu \mathrm{S} / \mathrm{Cm})$ & TDS & $\mathbf{C a}$ & Mg & $\mathbf{N a}$ & K & $\mathrm{CO}_{3}$ & $\mathrm{HCO}_{3}$ & $\mathrm{SO}_{4}$ & Cl \\
\hline pH & $*$ & & & & & & & & & & \\
\hline EC $(\mu \mathrm{S} / \mathrm{Cm})$ & -.392 & $*$ & & & & & & & & & \\
\hline TDS & -.057 & .852 & $*$ & & & & & & & & \\
\hline $\mathbf{C a}$ & -.435 & $.902^{*}$ & $.905^{*}$ & $*$ & & & & & & & \\
\hline Mg & -.632 & $.954^{*}$ & .687 & .839 & $*$ & & & & & & \\
\hline $\mathrm{Na}$ & .083 & .855 & $.967^{* * *}$ & .808 & .670 & $*$ & & & & & \\
\hline $\mathbf{K}$ & .370 & -.620 & -.541 & -.758 & -.577 & -.442 & $*$ & & & & \\
\hline $\mathrm{CO}_{3}$ & .309 & .346 & .095 & -.033 & .267 & .324 & -.067 & $*$ & & & \\
\hline $\mathrm{HCO}_{3}$ & .421 & .235 & .243 & .187 & .054 & .333 & -.597 & .605 & * & & \\
\hline $\mathrm{SO}_{4}$ & .510 & -.066 & .464 & .199 & -.285 & .389 & .076 & -.448 & -.033 & * & \\
\hline $\mathrm{Cl}$ & -.389 & $.994^{* *}$ & $.887^{*}$ & $.943^{*}$ & $.936 *$ & .868 & -.673 & .270 & .250 & .008 & * \\
\hline
\end{tabular}

For the groundwater samples, $\mathrm{pH}$ is directly correlated with $\mathrm{Mn}$ while $\mathrm{EC}$ is strongly correlated with TDS, $\mathrm{Ca}^{++}, \mathrm{Mg}^{++}, \mathrm{Na}^{+}, \mathrm{K}^{+}, \mathrm{SO}_{4}^{--}, \mathrm{Cl}^{-}, \mathrm{B}$ and $\mathrm{Sr}$ due to the role of lithologic impact, industrial wastes (B and $\mathrm{Sr}$ ) evaporation and dissolution of salts with precipitation, where it is weakly correlated with $\mathrm{PO}_{4}$ due to agricultural activity. TDS is strongly correlated with $\mathrm{Ca}^{++}, \mathrm{Mg}^{++}, \mathrm{Na}^{+}, \mathrm{K}^{+}, \mathrm{SO}_{4}^{--}, \mathrm{Cl}, \mathrm{B}$ and $\mathrm{Sr}$ due to evaporation and dissolution of evaporates in the fluvio-marine sediments that rich in gypsum and anhydrites while negative correlated with $\mathrm{HCO}_{3}{ }^{-}$and $\mathrm{CO}_{3}{ }^{-}$indicates recent recharge from Ismailia canal, as well as the dissolution of carbonate cement materials (Table. 5). $\mathrm{Ca}^{++}$is strongly correlated with $\mathrm{Mg}^{++}, \mathrm{Na}^{+}, \mathrm{K}^{+}, \mathrm{SO}_{4}^{--}, \mathrm{Cl}^{-}, \mathrm{Sr}$ and $\mathrm{B}$, this reflects the effect of evaporate dissolution $\left(\mathrm{CaSO}_{4}\right.$ and $\mathrm{CaCl}_{2}$ ) on the water chemistry and in agreement with the high correlation between TDS and both $\mathrm{SO}_{4}{ }^{-}$ -and $\mathrm{Cl}^{-}$. The strongly correlation between $\mathrm{Ca}^{++}$and $\mathrm{Mg}^{++}$is result of lithologic impact (dissolution of dolomite, calcite and high $\mathrm{Mg}$-calcite). The strong correlation with $\mathrm{SO}_{4}^{--}$and $\mathrm{Cl}^{-}$reflect a stage of dilution where the magnesium-chloride marine deposits is presented within the quaternary aquifer and reflected by the formation of $\mathrm{MgCl}_{2}$ and $\mathrm{MgSO}_{4}$ salts. $\mathrm{Mg}^{++}$is weakly correlated with $\mathrm{K}^{+}, \mathrm{Sr}$ and $\mathrm{B}$ due to agricultural and industrial activities. The good correlation between $\mathrm{Na}^{+}, \mathrm{SO}_{4}{ }^{-}$and $\mathrm{Cl}^{-}$could be attributed to the municipal contamination, evaporation, saline water intrusion and surface saline soils, this reflects the appearing of main water type $(\mathrm{NaCl})$ in the studied groundwater samples (Table. 5).

\section{Hierarchal cluster analysis (HCA)}

HCA has been successfully used in many earlier studies for evaluation and interpretation of groundwater quality data set in a worldwide scale (Hussain, 2004, Hussain et al., 2008, Kumar \& Riyazuddin, 2008, Rani \& Babu, 2008, Zhang et al., 2009 and Belkhiri et al., 2010). In HCA, clusters are formed sequentially, starting with the most similar pair of variables and forming higher clusters step by step. The result of clustering is a dendrogram representing the nested grouping of patterns and similarity levels at which groupings change. This dendrogram can be broken at different levels to yield different clusters of the data set. The HCA with Ward's method of linkages with squared Euclidean distance as dissimilarity measure was applied to detect multivariate similarities and to group parameters into clusters based on their similarities. The Ward's method of linkage uses the minimum variance approach to evaluate distance between clusters, (Jain et al., 1999), it has been found to provide meaningful dendrogram of clusters with the proximity or similarity of clusters measured with a rescaled distance.

Based on the Quaternary dendogram (Fig. 19), it is clear that there are two main clusters. The first one (cluster I) includes two sub-clusters the first includes $\mathrm{Na}^{+}, \mathrm{SO}_{4}{ }^{2+}, \mathrm{Cl}^{-}, \mathrm{EC}$ and TDS, while the second sub-cluster includes $\mathrm{Ca}^{2+}$ and $\mathrm{Mg}^{2+}$. The first sub-cluster indicates the relation between $\mathrm{EC}$ and TDS from one side and the major ions $\left(\mathrm{Na}^{+}, \mathrm{SO}_{4}{ }^{2+}, \mathrm{Cl}^{-}\right)$which are responsible for increasing 
Table 5: Pearson correlation matrix of the hydrochemical variables in the groundwater samples, Wadi El Tumilat area, Egypt.

\begin{tabular}{|c|c|c|c|c|c|c|c|c|c|c|c|c|c|c|c|c|c|c|c|}
\hline \multicolumn{20}{|c|}{ Groundwater } \\
\hline & pH & EC & TDS & $\mathrm{Ca}$ & Mg & $\mathbf{N a}$ & $\mathbf{K}$ & $\mathrm{CO}_{3}$ & $\mathrm{HCO}_{3}$ & $\mathrm{SO}_{4}$ & $\mathbf{C l}$ & B & $\mathrm{Sr}$ & $\mathrm{NO}_{3}$ & $\mathrm{PO}_{4}$ & Al & Mn & $\mathbf{V}$ & $\mathbf{Z n}$ \\
\hline pH & 1 & & & & & & & & & & & & & & & & & & \\
\hline $\mathbf{E C}$ & -.087 & 1 & & & & & & & & & & & & & & & & & \\
\hline TDS & -.093 & $.984^{* *}$ & 1 & & & & & & & & & & & & & & & & \\
\hline $\mathrm{Ca}$ & -.194 & $.889^{* *}$ & $.897^{* *}$ & 1 & & & & & & & & & & & & & & & \\
\hline Mg & -.225 & $.873^{* *}$ & $.872^{* *}$ & $.948^{* *}$ & 1 & & & & & & & & & & & & & & \\
\hline $\mathbf{N a}$ & -.042 & $.977^{* *}$ & $.986^{* *}$ & $.820^{* *}$ & $.799^{* *}$ & 1 & & & & & & & & & & & & & \\
\hline $\mathbf{K}$ & .060 & $.461^{* *}$ & $.462^{* *}$ & $.466^{* *}$ & $.442^{* *}$ & $.415^{* *}$ & 1 & & & & & & & & & & & & \\
\hline $\mathrm{CO}_{3}$ & $.493^{* *}$ & -.039 & -.076 & -.168 & -.128 & -.035 & .228 & 1 & & & & & & & & & & & \\
\hline $\mathrm{HCO}_{3}$ & .036 & -.202 & -.183 & $-.360^{* *}$ & $-.262^{*}$ & -.114 & -.167 & .101 & 1 & & & & & & & & & & \\
\hline $\mathrm{SO}_{4}$ & -.012 & $.821^{* *}$ & $.875^{* *}$ & $.687^{* *}$ & $.684^{* *}$ & $.880^{* *}$ & $.362^{* *}$ & -.074 & -.053 & 1 & & & & & & & & & \\
\hline $\mathbf{C l}$ & -.142 & $.953^{* *}$ & $.948^{* *}$ & $.932^{* *}$ & $.885^{* *}$ & $.912^{* *}$ & $.481^{* *}$ & -.091 & $-.339^{* *}$ & $.685^{* *}$ & 1 & & & & & & & & \\
\hline B & .086 & $.765^{* *}$ & $.753^{* *}$ & $.498^{* *}$ & $.515^{* *}$ & $.825^{* *}$ & .206 & .053 & .166 & $.757^{* *}$ & $.607^{* *}$ & 1 & & & & & & & \\
\hline $\mathbf{S r}$ & -.204 & $.825^{* *}$ & $.806^{* *}$ & $.926^{* *}$ & $.918^{* *}$ & $.732^{* *}$ & $.428^{* *}$ & -.121 & $-.421^{* *}$ & $.549^{* *}$ & $.883^{* *}$ & $.461^{* *}$ & 1 & & & & & & \\
\hline $\mathrm{NO}_{3}$ & .167 & .210 & .195 & .151 & .126 & .221 & .001 & .106 & $.254^{*}$ & .244 & .099 & $.389^{* *}$ & .100 & 1 & & & & & \\
\hline $\mathrm{PO}_{4}$ & -.123 & -.241 & -.240 & -.107 & -.140 & $-.274^{*}$ & .033 & -.144 & -.076 & -.210 & -.212 & -.176 & -.086 & -.063 & 1 & & & & \\
\hline Al & .007 & .085 & .065 & .052 & .079 & .074 & .049 & .117 & -.193 & .140 & .022 & .122 & .077 & .002 & .180 & 1 & & & \\
\hline Mn & $-.319^{*}$ & $-.393^{* *}$ & $-.371^{* *}$ & $-.277^{*}$ & -.214 & $-.408^{* *}$ & -.023 & -.038 & .159 & -.215 & $-.415^{* *}$ & $-.261^{*}$ & -.241 & -.021 & $.419^{* *}$ & .141 & 1 & & \\
\hline $\mathbf{V}$ & .061 & $-.251^{*}$ & $-.265^{*}$ & -.203 & -.190 & $-.256^{*}$ & -.232 & .135 & $.283^{*}$ & -.242 & $-.278^{*}$ & -.114 & -.146 & $.522^{* *}$ & -.061 & -.109 & .011 & 1 & \\
\hline Zn & .030 & -.027 & -.034 & .063 & -.034 & -.073 & $.278^{*}$ & .052 & -.131 & -.112 & .040 & -.164 & -.041 & -.106 & .110 & -.090 & .001 & -.001 & 1 \\
\hline
\end{tabular}

**. Correlation is significant at the 0.01 level (2-tailed).

*. Correlation is significant at the 0.05 level (2-tailed). 
groundwater salinity groundwater from the other side. The second sub-cluster indicates the cations which are included in the ion exchange process $\left(\mathrm{Ca}^{2+}\right.$ and $\left.\mathrm{Mg}^{2+}\right)$. On the other hand, the second cluster (cluster II) includes $\mathrm{CO}_{3}{ }^{2-}$ and $\mathrm{pH}$ which indicate the effect of $\mathrm{CO}_{3}{ }^{2-}$ on the degree of acidity (expressed as $\mathrm{pH}$ ). Furthermore, $\mathrm{HCO}_{3}{ }^{-}$stands as an independent case (i.e., without any relation to other ions).

For the Miocene dendrogram (Fig. 20), there are three clusters identified. The cluster (I) represents the major cations, $\mathrm{Cl}^{-}, \mathrm{EC}$ and TDS which indicate the most ions that control the salinity of groundwater at the Miocene aquifer. The cluster (II) represents the anions of weak acids $\left(\mathrm{CO}_{3}{ }^{2-}\right.$ and $\mathrm{HCO}_{3}{ }^{-}$) showing the meteoric recharge from surface water canals, while the cluster (III) represents $\mathrm{SO}_{4}{ }^{2-}$ and $\mathrm{pH}$ which reflects the relation between acidity of the Miocene groundwater and $\mathrm{SO}_{4}{ }^{2-}$ ion concentration (which forms in combination with $\mathrm{H}^{+}$the conc- sulfuric acid).

\section{Conclusion}

The present study deals with the hydrogeochemistry of the Quaternary aquifer and the impact of different hydrogeochemical processes on the quality of groundwater encountered at both Quaternary and Miocene aquifers of Wadi El Tumilat area and its vicinities. The chemistry of groundwater was outlined through the analysis of major cations and anions as well as the ionic ratios which indicate the relations between these cations and anions. The salinity of the Quaternary groundwater ranges from 194.7 to $4916.4 \mathrm{mg} / \mathrm{l}$ with an average value of $2586 \mathrm{mg} / \mathrm{l}$ which indicate fresh to brackish water category for $84.1 \%$ of groundwater samples and saline water category for $15.9 \%$ of samples. The main hydrogeochemical processes affecting groundwater quality at the Quaternary aquifer are: ion exchange, silicate weathering, evaporation and mixing with surface water and/or Miocene groundwater. The chloro-alkaline indices indicate that the dominant ion exchange process is of a reverse (indirect) type because it leads to enrichment of sodium ion in groundwater. The ionic ratios (either simple or complex) are used to demonstrate the prevalence of silicate weathering and evaporation at the Quaternary groundwater environment. The multivariate statistical analyses (mainly; correlation matrix analysis and hierarchical cluster analysis) were used effectively in the assessment of the hydrogeochemical processes affecting groundwater composition in the study area (especially the ion exchange and groundwater salinization).

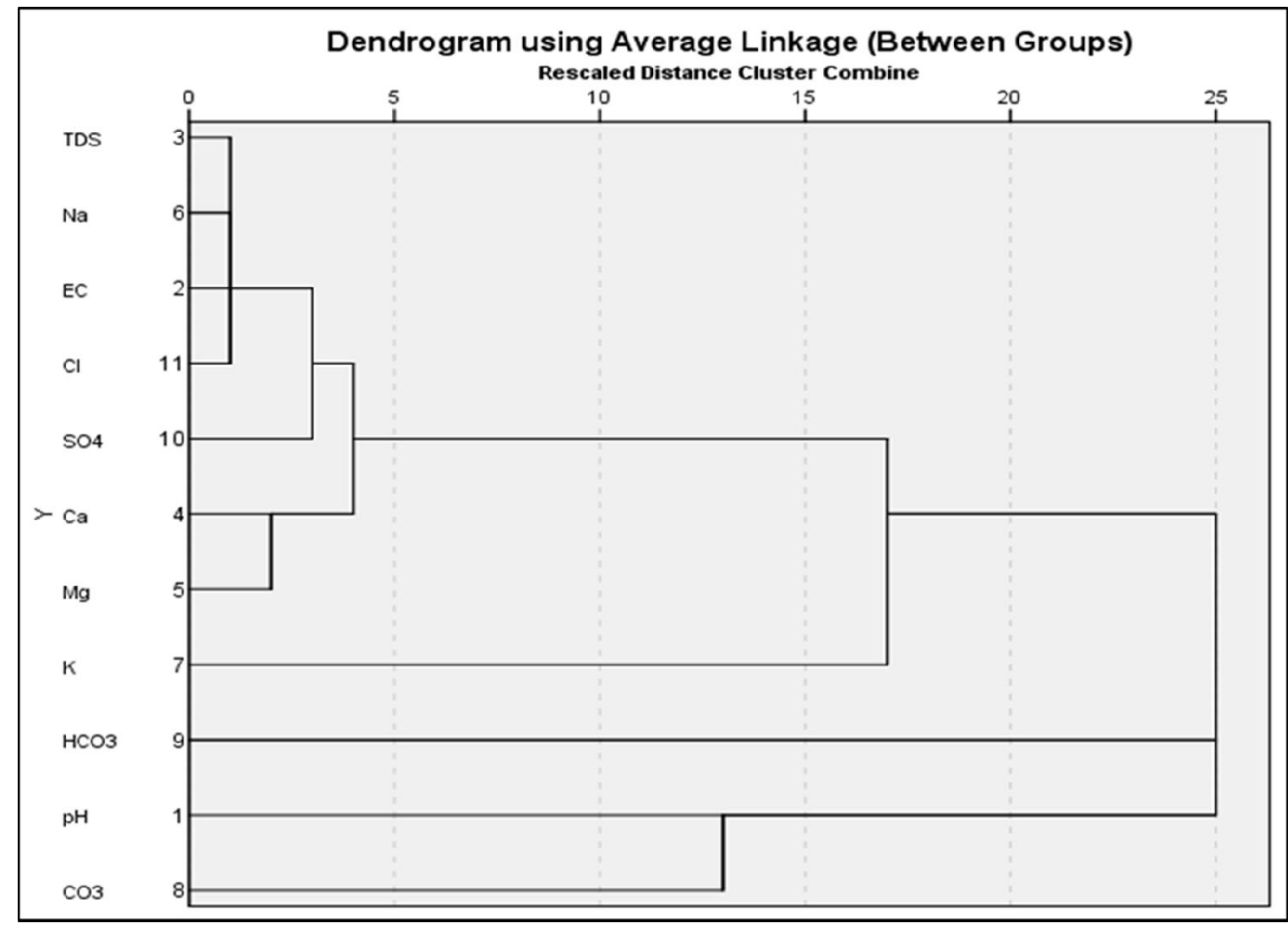

Fig. 19: Dendrogram (tree diagram) from cluster analysis for the Quaternary groundwater samples collected from Wadi El Tumilat area, Egypt 


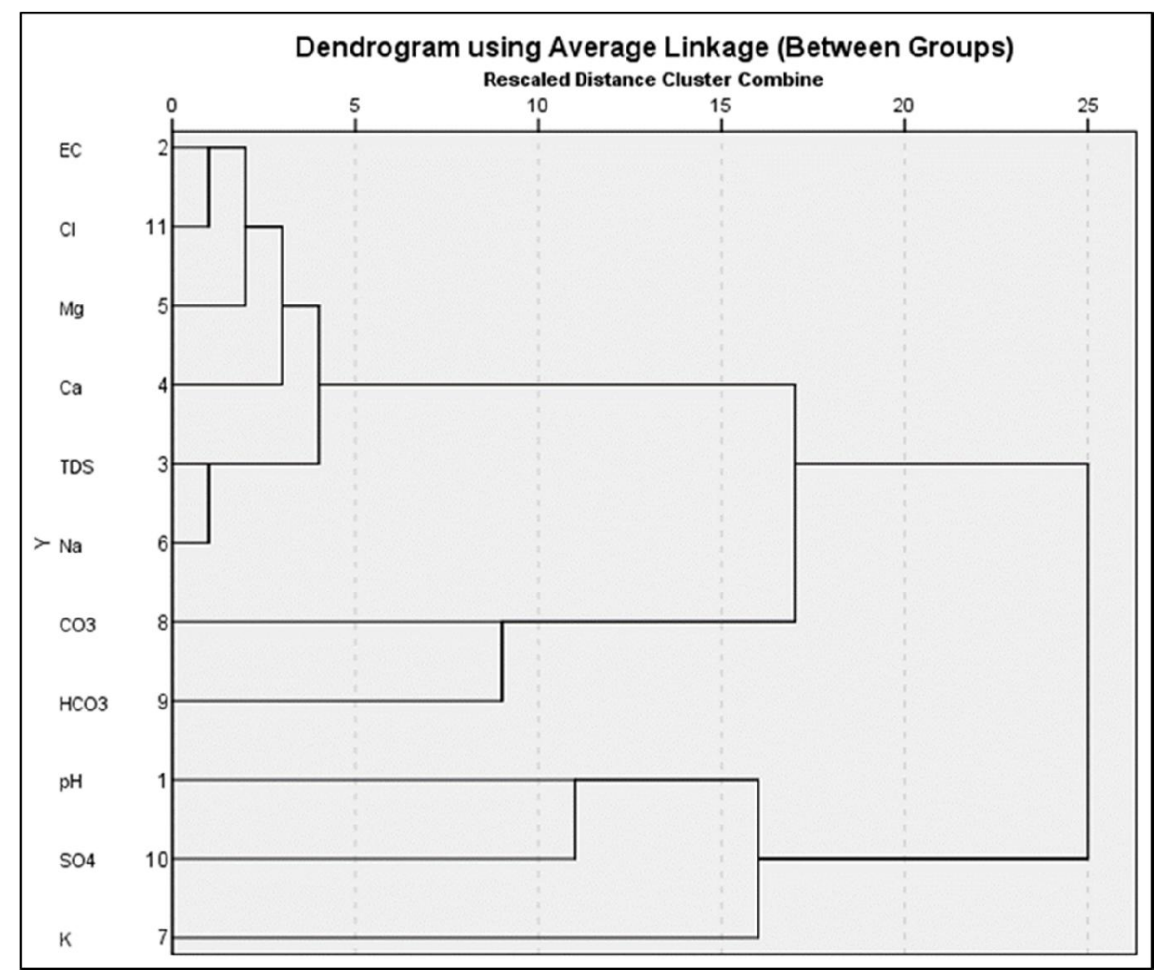

Fig. 20: Dendrogram (tree diagram) from cluster analysis for the Miocene groundwater samples collected from Wadi El Tumilat area, Egypt.

\section{Acknowledgments}

The authors would like to acknowledge the help of Mr. Mohamed Salah (at the Economic and Social Studies Division, Desert Research Center) in the collection of water samples from the area under investigation.

\section{References}

APHA, American Public Health Association, 1995. Standard methods for the examination of water, and waste water. $17^{\text {th }}$ edn. Washington DC, USA.

ASTM, American Society for Testing, and Materials, 2002. Water, and environmental technology. Annual book of ASTM standards, U.S.A. Sect. 11.Vols.11.01, and 11.02, West Conshohocken.

Belkhiri, L., A. Boudoukha, L. Mouni, and T. Baouz, 2010. Multivariate statistical characterization of groundwater quality in Ain Azel plain, Algeria. African Jour. of Environ. Sci., and Technology, 4(8): 526-534.

El Fawal, F.M., 1992. Sedimentology of the Quaternary south west of Ismailia, and its chronostratigraphy west of the Suez Canal. Proc., $3^{\text {rd }}$ Conf. Geol. Sinai Develop., Ismailia, pp. 141-152.

Dahab, K.A., E.A. ElAbd, M.K. Fattah and El Osta, M.M. 2007. Assessmentof groundwater problems of the Quaternary aquifer in the area between ElSalhia El Gidida - Abu Sweir, East Nile Delta, Egypt. GREMNA. 2:329-353.

El Fawal, F.M., and E.H. Shendi, 1991. Sedimentology, and groundwater of the Quaternary sandy layer north of Wadi EI-Tumilat, Ismailia, Egypt. Annals of the Geol. Surv. of Egypt. (17): 305314.

El Sayed, S.A., 2018. Contribution to the Ground Water Hydrology of the Quaternary Aquifer in West Ismailia Area, Egypt. Journal of Geosciences, and Environment Protection, 6, 134-158. https://doi.org/10.4236/gep.2018.67010. 
Gad, M.I., 1995. Hydrogeological studies for groundwater reservoirs, East of the tenth of Ramadan city, and vicinities. Unpublished M. Sc. Thesis, Ain Shams Univ.

Gad, M.I., M.M. El Kammar, and H.M. Ismail, 2015. Groundwater Vulnerability Assessment Using Different Overlay, and Index Methods for Quaternary Aquifer of Wadi El-Tumilat, East Delta, Egypt. Asian Review of Environmental, and Earth Sciences, 2(1): 9-22.

Geriesh, M.H., 1989. Hydrogeological investigations of west Ismailia area, Egypt, M. Sc. dissertation, Fac. of Sc., Suez Canal Univ., 132 p.

Geriesh, M.H., 1994. Hydrogeological, and hydrogeochemical evaluation for the groundwater resources in the Suez Canal region, Ph. D. Thesis, Suez Canal Univ., Egypt, 101 p.

Geriesh, M.H., 2000. Paleohydrogeological regime of groundwater flow in the eastern Nile Delta region, IV international Conference "Water supply, and water quality", Krakow- Poland, Sept. 11-13, 2000, 229- 241.

Geriesh, M.H., and A.E. El Rayes, 2001. Municipal contamination of shallow groundwater beneath south Ismailia villages, 5th Inter. Conf. on Geochemistry, Alex. Univ., Egypt, 12-13 Sept., 241253.

Gibbs, J. 1970. Mechanisms controlling world water chemistry. The Science, 170: 795-840.

Gomaah, M., T. Meixner, E. Korany, H. Garamoon, and M. Gomaa, 2016. Identifying the sources, and geochemical evolution of groundwater using sTable isotopes, and hydrogeochemistry in the Quaternary aquifer in the area between Ismailia, and El Kassara canals, Northeastern Egypt. Arab J Geosci 9 (437), DOI 10.1007/s12517-016-2444-4

Hefny, K., 1980. Groundwater in the Nile Valley, Ministry of Irrigation, Water Research Center, Groundwater Research Inst., (In Arabic), 120 p.

Herczeg, A.L., and W.M. Edmunds, 1999. Inorganic ions as tracers. Cook hydrology. Kluwer, Boston, 31-77.

Hounslow, A.W., 1995. Water Quality Data: Analysis, and Interpretation, CRC Lewis Publishers, Boca Raton, FL, 416 P.

Hussain, M., S. Ahmed, and W. Abderrahman, 2008. Cluster analysis, and quality assessment of logged water at an irrigation project, eastern Saudi Arabia. Journal of Environmental Management 86: 297-307.

Hussain, M.T., 2004. Hydrochemical evaluation of groundwater in the Blue Nile Basin, eastern Sudan, using conventional, and multivariate techniques. Hydrogeology Journal 12: 144-158.

Ismail, H.M.G., 2008. Study the vulnerability of groundwater aquifer for pollution in Wadi ElTumilat, Eastern Delta, Unpublished M.Sc. dissertation, Fac. of Sci., Cairo Univ.

Jain, A.K., M.N. Murty, and P.J. Flynn, 1999. Data Clustering: A Review. ACM Computing Surveys 31 (3): 264-323.

Kumar, A.R., and P. Riyazuddin, 2008. Application of chemometric techniques in the assessment of groundwater pollution in a suburban area of Chennai city, India. Current Science 94 (8), 10121022.

Mabrouk, B., F. Ramadan, M. Nagaty, and Y. abd El Azeem, 2016. Sedimentological, and Hydrogeochemical Studies of the Quaternary Groundwater Aquifer in El Salhyia Area, Sharkia Governorate, Egypt. Middle East Journal of Applied Sciences, 06(1): 120-138.

Mclean, W., J. Jankowski, and N. Lavitt, 2000. Groundwater quality, and sustainability in an alluvial aquifer, Australia. In: Sililo O et al (ed) Groundwater, past achievements, and future challenges. Balkema, Rotterdam, 567-573.

Mohapatra, P.K., R. Vijay, P.R. Pujari, S.K. Sundaray, and B.P. Mohanty, 2011. Processes affecting groundwater quality in Puri city, India. Water Science \& Technology, 64(4):809-817.

Papatheodorou, G., N. Lambrakis, and G. Panagopoulos, 2007. Application of multivariate statistical procedures to the hydrochemical study of a coastal aquifer: an example from Crete, Greece. Hydrological Processes 21 (11):1482-1495.

Rainwater, F.H., and L.L. Thatcher, 1960. Methods for collection, and analysis of water samples. U.S. Geol. Survey. Water Supply, Paper No.1454, U.S.A. 301pp.

Rani, A., and D.S. Babu, 2008. A statistical evaluation of ground water chemistry from the west coast of Tamil Nadu, India. Indian Journal of Marine Sciences, 37 (2): 186-192.

Reghunath, R.; Murthy, T. R.; Raghavan, B. R. 2002. The utility of multivariate statistical techniques in hydrogeochemicalstudies: an example from Karnataka, India. Water Research 36, 2437-2442. 
Revelle, R., 1941. Criteria for recognition of sea water in ground-waters. Eos, Transactions American Geophysical Union, 22, 593-597.

Ruiz, F., V. Gomis, and P. Blasco, 1990. Application of factor analysis to the hydrochemical study of a coastal aquifer. Journal of Hydrology, 119, 169-177.

Sallouma, M.K., 1983. Hydrogeological, and Hydrochemical Studies East of the Nile Delta, Egypt. $\mathrm{PhD}$ Thesis, Ain Shams University, Cairo.

Schoeller, H., 1967. Qualitative evaluation of groundwater resources. In Methods, and techniques of groundwater investigation, and development. Water Research, Series-33. UNESCO (eds.), 44-52.

Shata, A.A., 1965. Geological structure of the Nile Delta. Jour. of Engin. Cairo, (in Arabic), pp. 1-3.

Singh, K.P., A. Mali, V.K. Singh, D. Mohan, and S. Sinha, 2005. Chemometric analysis of groundwater quality data of alluvial aquifer of Gangetic plain, North India. Analytica Chimia Acta., 550 (1-2), 82-91.

Singh, S.K., C.K. Singh, K.S. Kumar, R. Gupta, and S. Mukherjee, 2009. Spatial-temporal monitoring of groundwater using multivariate statistical techniques in Bareilly District of Uttar Pradesh, India. Journal of Hydrology, and Hydromechanics, 57 (1), 45-54.

Todd, D.K., 1959. Ground water hydrology. Chapman \& Hall inc., London. 336 page. https://doi.org/10.1002/qj.49708737126.

Zhang, Q., Z. Li, G. Zeng, J. Li, Y. Fang, Q. Yuan, Y. Wang, and F. Ye, 2009. Assessment of surface water quality using multivariate statistical techniques in red soil hilly region: a case study of Xiangjiang watershed, China. Environ Monit Assess., 152:123-131, DOI 10.1007/s10661-0080301-y. 